Florida International University FIU Digital Commons

FIU Electronic Theses and Dissertations

University Graduate School

2-23-2015

\title{
The Commodification of Queer Virgins in Shakespeare, Spenser, and Keats
}

Laura M. Ortega

Florida International University, lorte002@fiu.edu

DOI: $10.25148 /$ etd.FI15032126

Follow this and additional works at: https://digitalcommons.fiu.edu/etd

Part of the Feminist Philosophy Commons, Literature in English, Anglophone outside British Isles and North America Commons, and the Other Feminist, Gender, and Sexuality Studies Commons

\section{Recommended Citation}

Ortega, Laura M., "The Commodification of Queer Virgins in Shakespeare, Spenser, and Keats" (2015). FIU Electronic Theses and Dissertations. 1905.

https://digitalcommons.fiu.edu/etd/1905

This work is brought to you for free and open access by the University Graduate School at FIU Digital Commons. It has been accepted for inclusion in FIU Electronic Theses and Dissertations by an authorized administrator of FIU Digital Commons. For more information, please contact dcc@fiu.edu. 


\section{FLORIDA INTERNATIONAL UNIVERSITY}

Miami, Florida

\section{THE COMMODIFICATION OF QUEER VIRGINS IN SHAKESPEARE, SPENSER, AND KEATS}

A thesis submitted in partial fulfillment of the requirements for the degree of

MASTER OF ARTS

in

ENGLISH

by

Laura Ortega

2015 
To: $\quad$ Dean Michael R. Heithaus

College of Arts and Sciences

This thesis, written by Laura Ortega, and entitled The Commodification of Queer Virgins in Shakespeare, Spenser, and Keats, having been approved in respect to style and intellectual content, is referred to you for judgment.

We have read this thesis and recommend that it be approved.

Maneck Daruwala

Ana Luszczynska

James Sutton, Major Professor

Date of Defense: February 23, 2015

The thesis of Laura Ortega is approved.

Dean Michael R. Heithaus College of Arts and Sciences

Dean Lakshmi N. Reddi University Graduate School

Florida International University, 2015 


\section{DEDICATION}

To my mother, who instilled in me the very first strains of feminism and bibliophilia. 


\section{ACKNOWLEDGMENTS}

I would like to thank Dr. Sutton, who has guided me expertly through the timeless beauty that is Shakespeare and has never failed to provide encouraging, constructive feedback on my work.

I'd also like to thank Dr. Luszczynska, who first introduced me to literary theory, thereby removing the ideological ground upon which I so misguidedly stood. Also for being kind enough to tell me I actually understood Heidegger and Derrida.

Finally, to Dr. Daruwala for her unwavering kindness and, though not included in this particular thesis, for introducing me to Lord Byron, whom I feel is a kindred spirit. 


\author{
ABSTRACT OF THE THESIS \\ THE COMMODIFICATION OF QUEER VIRGINS IN SHAKESPEARE, SPENSER, \\ AND KEATS \\ by \\ Laura Ortega
}

Florida International University, 2015

Miami, Florida

Professor James Sutton, Major Professor

The purpose of this thesis was to explore selected works from William

Shakespeare, Edmund Spenser, and John Keats, in order to expose textual instances of feminist thought. This analysis was aided with feminist theorists falling under the main strains of queer theory, materialism, and gender performance. Specifically, this thesis focused on the ways in which women, particularly virgin daughters, were viewed as property by their male kin. It also looked at how these women engaged in various symbolic masquerades and/or actual cross-dressing as a response to the aforementioned phenomenon. Finally, the thesis exposed how these masquerades can be construed as a queering of identity_manifested through reversals of power and rejection of patriarchal institutions like marriage. 


\section{TABLE OF CONTENTS}

CHAPTER

PAGE

INTRODUCTION

The Commodification of Queer Virgins in Shakespeare, Spenser, and Keats

CHAPTER ONE

Shakespearean Daughters in Transsexual Masquerade

CHAPTER TWO

Spenserian Virgins: The Repudiation of Marriage and Perpetuation of Power.

.38

CHAPTER THREE

Performing Power: Queer Virgins in Keats's Poetry

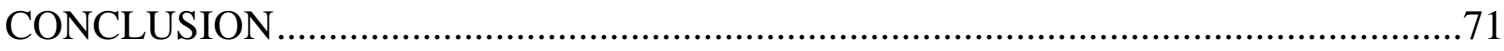

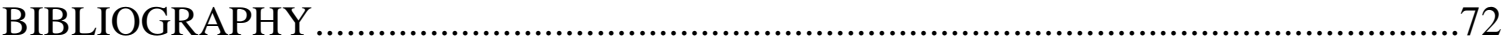




\section{INTRODUCTION}

The Commodification of Queer Virgins in Shakespeare, Spenser, and Keats

A number of feminist concerns arise in British poetry and plays from the Early Modern period to the Romantic Movement. Of particular interest to the present work will be issues surrounding gender performance and material feminism—-that is, the female virgin as a commodity. In Materialist Feminism and the Politics of Discourse, Rosemary Hennessy cites Christine Delphy, among others, in differentiating between Marxist and Materialist Feminism thus: "...Marxism cannot adequately address women's exploitation and oppression unless the Marxist problematic itself is transformed so as to be able to account for the sexual division of labor" (xi). With its emphasis on the historical means of production in an entirely deterministic way, Marxism fails to account for patriarchal power structures, which are of major concern for feminist thinkers.

Hennessy also notes how the social construction of "woman" is never "monolithic," and instead should be thought of as a "discursive category" (xii). Although many would automatically hold that discourse has no impact on material reality, Hennessy warns against this. Language and institutions of knowledge have very real, material effects on their subjects. These subjects are in turn shot through with differences, and these differences are founded on a hierarchy of inequality. The most important of these dominant hierarchies, for materialist feminism, are patriarchy and capitalism. These are historically developed and systemically sustained through the prevailing discourse. Their effects are manifested socially and can be problematized via the invisible, abstract form of feminist theory or the highly visible (though not always recognized), concrete forms of women's roles being predetermined by tyrannical gender relations. In other 
words, we can speak abstractly about a virgin’s symbolic “price,” while in lived reality, these girls and women became flesh items in a barter system. This reality is still reinforced within a discursive framework—a language that imbues "virginity” and “chastity” with positive connotations, clearly steeping both men and women in the belief that the opposite is undesirable and even threatening to the established order.

We employ the term “commodity” in the Marxist-Materialist understanding where the token of exchange has market value for its owner. This term, however, adapts a symbolic meaning when applied to the female virgins in the works of Spenser, Shakespeare, and Keats. In their writing, we note how men (often the fathers) control the value and barter the "price” of the virginal daughter. Ownership is then passed from father to husband within the institution of marriage. While some virgins readily submit, many defiantly counter such commodification in a definite "queering” of their sexual identities, leading to such phenomena as the masquerade and the rejection of marriage. When speaking of the feminine masquerade and the motives behind it, it is useful to engage in Lacanian discourse, which presents the phallus as the transcendental signifier of human desire. Accepting this semiotic notion, desire is what Freud claimed to be the driving force for human behavior; whether certain desires were repressed or not leads to the vicissitudes of individual psychology. The presence of desire necessitates an absence of something else, and so the phallus as a symbolic structure parallels the metonymic nature of language, where one is led in an endless chain of signifiers. For Lacan, the woman is the phallus (that is, the object of desire) while the man is the subject, creating an interdependence that is nonetheless unequal, as will be shown shortly. So while the phallus (woman) is the object of desire, it (she) is possessed only by man. The 
man needs the phallus insofar as he wields independence and authority over it. Thus the anatomical and symbolic phallus become interchangeable, since he that owns the first controls the second. She that lacks it becomes a petitioner for its privileges, assuming the submissive role. This is combatted by donning either the masculine or the feminine “masque” for the appropriation or exploitation of phallic power.

In her authoritative polemic Gender Trouble, Judith Butler differentiates between “being” the Phallus and “having” the Phallus within Lacan's intersection of gender and language:

To "be" the Phallus is to be the "signifier" of the desire of the Other and to appear as this signifier. In other words, it is to be the object, the Other of a (heterosexualized) masculine desire, but also to represent or reflect that desire. This is an Other that constitutes, not the limit of masculinity in a feminine alterity, but the site of a masculine self-elaboration. For women to "be" the Phallus means, then, to reflect the power of the Phallus, to signify that power, to "embody" the Phallus, to supply the site to which it penetrates, and to signify the Phallus through "being” its Other, its absence, its lack, the dialectical confirmation of its identity. (56)

In other words, the phallic presence in the identity of man is defined by the woman's phallic absence. Ages before Freud based female sexuality on penis-envy, it was Aristotle who said, "Without exception, every woman wants to be a man, by reason of a certain instinct that teaches her to desire her own perfection” (qtd. in Finucci, Schwartz 76). For the greater part of his life, the female struggle for power was largely negligible or otherwise inconsequential to Freud and thus written off as an enigma, as with his 
reference to female sexuality as the "dark continent” (Finucci 135). Freud ended his life leaving contradictions in his wake and the question of female sexuality unanswered. Although Lacan addressed this question with his assertion of woman as the phallus, it remained a phallocentric standpoint in its complimentary yet inequitable placement of the man as center and the woman as the outside object of desire. The state of womanhood is that of alterity, imbued with lacking and Otherness. This hierarchical binary opposition creates a condition where a woman's worth orbits the man. It identifies the woman's sole purpose as providing a site of penetration for the man to achieve his identity in the face of her deficiency. Although this dynamic is interdependent, it is not mutually beneficial, at least not evenhandedly. Butler describes the relation between being and having the phallus as analogous to that of the slave and the slave owner. While the slave owner's identity depends upon the slave, it cannot be said that the object of desire (slave) has any power over the subject who desires (slave owner) (54).

The woman's struggle to "have” instead of "embody" the phallus can be summed up as the masquerade, first introduced by Lacan. He describes the mask as the mark of a heterosexual comedy in which gender relations are performed at will, suggesting that both having and being the phallus are illusions. Irigaray remarks in stride that "the masquerade ... is what women do ... in order to participate in man's desire, but at the cost of giving up their own” (qtd. in Butler 54). In order to agree with Butler here, we would have to also concede that all women are giving up their true desire (even subconsciously perhaps) and playing the role that has been given to them. Many are so entrenched in the ideology, they cannot fathom an alternate subjectivity. Butler's claim here seems to echo Slavoj Žižek’s in saying that we are never really "outside ideology.” 
Indeed, just when we think we are most outside of it, is when we are most within it. Stretching the point almost to breaking would be to say that all heterosexual women are deluded in one way or another. This, of course, makes the problematic assumption that female desire and sexuality are fixed constructs, though we have already confirmed femininity/masculinity as masquerades. Riviere explains the prevalent female desire to overthrow men, particularly the father:

The rivalry with the father is not over the desire of the mother, as one might expect, but over the place of the father in public discourse as speaker, lecturer, writer - that is, as a user of signs rather than a sign-object, an item of exchange. This castrating desire might be understood as the desire to relinquish the status of woman-assign in order to appear as a subject rather than object within language. (qtd. in Butler 66)

The masquerade is an attempt to reject patriarchal hierarchy either by masculine disguise or employing man’s desire using a feminine disguise to serve a female agenda. Both cases however, are women's responses to a male-dominated situation, whether as outright rejection (masculine masquerade) or subversive exploitation (feminine masquerade). Lacan tells us that being a woman is inextricably tied to masquerade: "it is in order to be the phallus, that is to say the signifier of desire of the Other, that the woman will reject an "essential” part of her femininity, notably all its attributes through masquerade. It is for what she is not that she expects to be desired as well as loved” (qtd. in Butler 85).

In the Symbolic order, the Law, or father, has a different effect upon the son and the daughter. The son experiences a threat of loss of the phallus, while the daughter must 
cope with the fact that she never had this thing to begin with. So while the son can partake of the phallic joys of masculinity, the daughter must look for a substitute property of which she can feel pride. While we must not confuse phallus as organ with phallus as metaphor, (the second of which Lacan meant when he used the term) it is difficult to separate the abstract from the concrete, especially when, of all linguistic signifiers, he chooses this one. Even though using it as a metaphor, we are reminded of Jacques Derrida in saying that the choice of one or another metaphor is never incidental.

In any case, this constant repression of desire for the phallus defines what the woman is. She longs for this transcendental signifier, as Lacan puts it, because everything else springs from it. The son already owns it and so fights never to lose it, thereby identifying with the father in a purely selfish (and unconscious) attempt to depose him in the future. What can be said then about the female characters that act as sons? As Lady Macbeth longed to, how and why have these characters been "un-sexed?"

The chosen plays lack an important figure in the Symbolic order: the mother. Although her involvement is implied by the presence of children, she is absent from the action of the plot and we do not see an interaction between her and the daughter, which places even more emphasis on the father-daughter relationship. The state of doubled "motherlessness" in the plays (the Shakespearean heroines lack both a mother and their own child) portends an increased demand for the rupture of pre-Oedipal attachment to the mother and submission to the father's desire. Pre-oedipal refers to the state of being truly inseparable from the mother, where subjectivity is not yet conceived as individuality. For Freud and Lacan, a sense of individual identity is developed once the child is introduced to the father. This brings about the realization that it (the child) is in fact a separate entity 
from the mother. This phenomenon is prompted via the realization of sexual differenceeither from the father or from the mother. In any case, however, it is traumatic encounter in many ways; a shattering and re-forming of identity. This experience is further exacerbated through language, that is, different names for biological organs, different terms for each parent, gender, etc. Finucci alludes to biblical text in describing this demand to submit to the father:

Eve literally comes into existence only in relation to her father's desire for her, needing to acknowledge him as her one true parent. And because her parent is also her husband, Eve is taught, from birth on, to respond to male desire: she is created by Adam as the object of his desire, and she is re-created by Satan as the object of his desire. But what does Eve want? (160)

Following the object lust that drives the notion of penis-envy, the daughter comes to understand that while she lacks the phallus, she will have the fetus. Since she needs a masculine figure to produce the fetus, she idolizes the father whose possession of the phallus can provide this. For Freud, the son has a clear reason to separate from the mother, but the daughter has no real reason to cut the incestuous love for the father, since the threat of castration that the Law (father) presents is irrelevant to the already castrated daughter. In other words, the mother cannot threaten the daughter with the removal of anything, because the daughter is born "deficient” and will remain deficient until she produces the fetus. To subvert the unconscious desire that young boys have for their mother, the father must present an unpleasant consequence. What follows is the youth becoming a man and growing old with a latent desire for his mother, and the successful repression of this desire defines the person he will become. Take the same situation with 
the girl, and there is no clear consequence for her continuation of desire for the father, so how can one be sure that it was ever repressed? These are the daughters that represent the "ideal" insofar as they do not compete with the father, identify with the mother, and so masquerade femininity. They accept themselves as castrated and use their object status as a means to entice first their father's desire and later their husband's.

Female masquerading has distinct and opposing purposes. Some daughters will masquerade overt femininity as a means to fulfill generalized male expectations and desire. Their end goal is to fit neatly into the filial and marriage institutions they have come to understand. In Shakespeare's world, the ideal daughters have a non-competitive, submissive relationship towards the father (in Lacanian lexicon, also the Law). This dynamic also appears in the works of Spenser where father-daughter strife (or fatherfigures in Keats) is seen as a sign of female transgression, and arguably, a "queering” of her identity. When the Law enters the dyadic bond between mother and child, he creates the triangle that in turn sexualizes the child, a phenomenon termed the Symbolic Order.

The filial system for royal command is gender specific with a strong adherence to Lacanian Symbolic Order. Only the ideal daughter finds no need to compete with the father in order to prove herself worthy in his role, as she accepts herself as inexorably "castrated" and thus powerless and assumes the feminine masquerade in attempt to exploit male desire. The acceptance of castration is crucial, as we will see that Oedipal daughters reject it wholeheartedly and adopt a mode of overt rebellion. Shakespeare, as so often, provides excellent examples of this phenomenon. In King Lear, the purely "feminine" representative of Cordelia is not in competition with her father. Perhaps a certain degree of discord will strain the relationship momentarily due to the father 
imposing his will upon the daughter, but all will be happily (or tragically) solved by the conclusion of the play, and most notably, the daughter will indirectly yield to the father's original demand. The father's wish is always granted, unbeknownst to the daughter and oftentimes to the audience itself. Lear wished for his daughter to prove her affection, and although she did not initially comply in words, she ultimately fulfilled his desire at a deeper level than he thought possible. Cordelia began as an Oedipal daughter when she defied her father's original demand, but converted to the feminine ideal post-banishment. It was after this undeserved punishment that her actions fulfilled the feminine model as being devoted to her father in spite of his immense wrongdoing. Lear's older daughters merely masqueraded as feminine ideals by feigning a servile commitment and exclusive affection towards their father (and notably excluding their husbands). To Lear, this false show of affection was taken as a flattering display of the father-daughter dynamic and larger gender relations that he deemed "natural."

The daughter can however achieve vicarious access into phallic power when she identifies with the father and rejects her castration. Riviere builds on Lacan's masquerade as she introduces the woman who "wishes for masculinity" as homosexual only in terms of sustaining a masculine identification, but not in terms of a sexual orientation or desire. These female homosexuals use the mask as a shield: "his first group of homosexual women who, while taking no interest in other women, wish for 'recognition' of their masculinity from men and claim to be the equals of men, or in other words, to be men themselves” (qtd. in Butler 66). Yet for the virginal daughters we speak of, it is not enough to reverse the hierarchy and still be considered "queer." Employing a set of stereotypically "male" traits in order to gain leverage is not a questioning of identity, but 
rather, acquiescence into the patriarchal game. While the virgins in Shakespeare's tragedies are written off, those in his comedies and in Spenser and Keats' poetry achieve much more: they satirize the masculine and feminine performance, push back against the institution of marriage, and question the very core of what it means to be "woman."

Absence of a male heir causes other Shakespearean daughters to become substitute sons, the repression of their Oedipal rivalry bursting forth with their defiance. In such daughters, the fear of castration represents the loss of the symbolic rather than reified phallus they possess. Until the rising action of the plot that will lead to their eventual subjugation or death, they have been living relatively unhindered by patriarchal mores. Once the question of inheritance or independence comes into play, these unruly daughters must all of a sudden be cowed. Such a grievous loss of authority causes rebellion which is ultimately subdued from above, i.e., the author. Oedipal daughters will either be tamed or terminated—sometimes both. “Oedipal daughters” also interchanges with "queer virgins" in their threat to the Law of the Father and the identity politics of patriarchy, respectively. Cordelia is a pointed example of both. With fierce conviction she tells her father she will not play into his game of flattery. After Lear banishes her, she is arguably "tamed," in her steady concern and aid to him, despite his seriously misguided judgment. Cordelia's life is undeservedly extinguished even after Shakespeare has converted her into the ideal daughter serving the law of the father.

A daughter can be textually masqueraded as a son in the same way prepubescent boys are dramatically masqueraded as females aided by costume, makeup and the opportune absence of facial hair. "Masquing” can be done in the literary sense, with perhaps an unconscious desire for phallic license. In Shakespeare, daughters dissent from 
the Law of the Father either because they seek independence from domination, or seek to dominate as Ruth Hoberman tells us, by "masquing the phallus” (6). The masque offers transcendence of gender identity. From Ancient Greek to Elizabethan times, for women who forcibly abstained from the stage, the masque was a giveaway that whatever the gender it depicted, the body behind it was male. The masque was capable of evoking the power of transgender while also implying masculinity, since historically the person with the autonomy to make these changes was surely male. When daughters put on their male narrative masque, they are simultaneously asserting their masculinity (in their freedom to assume the masque) and their transcendence of gender (in that the masque could signify either gender). Thus the woman, by donning the masque, possesses the symbolic phallus while asserting gender as a disguise itself, not at all determined by biological taxonomy.

Freud terms castration as an essential anatomic condition of women, bearing the debasement of lacking the physical attribute that gives you authority: the phallus. In the effort to gain personal and/or extended authority, daughters will assume a traditionally son-associated psychology and thus assume the Oedipal "masque," or a façade of masculine opposition. The associated behavior with the masque creates strife with the father so as to assume the seat of authority and independence. These efforts serve the women as a rejection of castration and a disavowal of the lack of privileges therein. Hoberman maintains "it is not an attempt to become a male but a refusal to be seen unproblematically as 'female”' (7).

The goal then, is not a hierarchical reversal, but a critical interrogation of the hierarchical structure of identity itself. In Volume I of The History of Sexuality, Foucault provides us with an apt framework for interrogating not just gender, but sexuality, the 
power dynamic between the sexes, and the ways we speak about sex in general. He denies any real censorship of sex, claiming instead that "[t]here was installed rather an apparatus for producing an ever greater quantity of discourse about sex, capable of functioning and taking effect in its very economy” (23). The effectiveness of this apparatus is due to its entering into our collective discourse and therefore consciousness in ways that cannot be denied, no matter how many would claim that it existed in silence. The very uttering of such a hypothesis validates its presence, even when expressed in exclusively negative terms, as he makes clear: "To say that sex is not repressed, or rather that the relationship between sex and power is not characterized by repression, is to risk falling into a sterile paradox" (8). Speaking about sex, sexuality, and the intersection of sex and power in these terms is to delegitimize the historical lived reality of repression. By speaking of it in negation, one not only denies this history, but also precludes any honest discussion and attempts at opening it to questioning.

The subtle ironies behind the discursive presence of sex did not, for Foucault, mask its agenda as an apparatus of control: "One had to speak of sex... as of a thing to be not simply condemned or tolerated but managed, inserted into systems of utility, regulated for the greater good of all, made to function according to an optimum. Sex was not something one simply judged; it was a thing one administered” (24). So, not only was it vitally important to express it in prohibitive terms, it was equally important to devise its commodification. Certain kinds of sex and its incarnations were bio-politically profitable, and had to be meticulously documented: "birthrate, the age of marriage, the legitimate and illegitimate births, the precocity and frequency of sexual relations, the ways of making them fertile or sterile, the effects of unmarried life or of the prohibitions, the 
impact of contraceptive practices,” (25-26) and so on. In essence, then, the state "tried to transform the sexual conduct of couples into a concerted economic and political behavior” (26).

This assertion rings particularly loud when considering the young women subjected to the topic of this discussion. In engaging the question of their commodification, we are reinforcing Foucault’s claim that, far from “consign[ing] sex to a shadow existence, [modern societies have] dedicated themselves to speaking of it ad infinitum, while exploiting it as the secret” (35). However, we do not engage in categorization or value judgments as befitted his argument, but rather in an open questioning of these defining powers. These powers also rest assuredly on the binary of licit and illicit sex, or in other words, productive and unproductive sexuality. Unproductive, or illicit sex and sexuality “[was] not amenable to the strict economy of reproduction” (36), was dangerous to patriarchy, and was therefore prohibited. The very idea of "fruitless pleasures" (36), thought to be perverse, screams commercial enterprise: “to ensure population, to reproduce labor capacity, to perpetuate the form of social relations: in short, to constitute a sexuality that is economically useful and politically conservative” (36-37). Thus, heterosexual matrimony became the bulwark against this danger:

...the marital obligation, the ability to fulfill it, the manner in which one complied with it...its fecundity or the way one went about making it sterile, the moments when one demanded it (dangerous periods of pregnancy or breast-feeding, forbidden times of Lent or abstinence)...the sex of husband and wife was beset by rules...[and] the 'rest' remained a good deal more confused (37). 
Foucualt cites the mythical character of Don Juan (Tirzo de Molina’s) as the "great violator" (39) of these very establishments. By stealing or seducing wives and virgins, he in effect insulted husbands and fathers—since it was their property he stole and defaced.

By mentioning the "rest," Foucualt meant those not neatly fitting into heterosexual relations, the "confusion” being synonymous with threat. Foucault tells us that for quite some time, "hermaphrodites were criminals, or crime’s offspring, since their anatomical disposition, their very being, confounded the law that distinguished the sexes and prescribed their union” (38). Yet it is not simply anatomical confusion that posed a threat, but queer sexual preferences and attitudes as well: "Homosexuality appeared as one of the forms of sexuality when it was transposed from the practice of sodomy onto a kind of interior androgyny, a hermaphrodism of the soul” (43). So it was that an isolated behavior developed into what Foucault termed a "species" (43) and what we may refer to as a queer subjectivity. Whether or not this subjectivity is another form of identity politics remains to be seen. For Foucault, sex and sexuality, not as constructs of "nature," but as discursive categories, have come to define who we are. The ways in which we have sex, the desires we give in to, and those we don't, all constitute a matrix upon which our sexual identity rests. In spite of the questionable logic behind the construction of such a thing as "sexual identity," we can recognize, as Foucault did, the historical and patriarchal tendency to mark queer sexualities as something proscribed and repressible. Oscar Wilde is called to mind when saying, "Everything in the world is about sex, except sex. Sex is about power.” The pursuit of sex in an idealized patriarchal world 
is one of acquisition on the part of the man, and compliance on the part of the woman. Some women, however, fight to reverse or otherwise dismantle this power.

The first chapter in this thesis, "Shakespearean Daughters in Transsexual Masquerade," draws from selected Shakespearean tragedies and comedies, exploring the motivations behind virgin daughters' masquerades, and the ways in which they do so, while noting the new husband's transition to second father. Here, our main object is to show that both the feminine and masculine masquerades are subversive attempts against phallocentric culture. The credibility of the masquerade is a testament to the fluidity of gender. Prior to this, however, we strive to understand why daughters' masquerades are products of a gender hierarchy ruled by the phallus.

In the second chapter, "Spenserian Virgins: The Repudiation of Marriage and Perpetuation of Power," we will turn to Edmund Spenser's works to explore the institution of marriage with the virgin as a central contingency. From a materialist perspective, the virgin becomes a commodity within the patriarchal economy of father and future son-in-law as seller and buyer. Spenserian virgins like Britomart (and other embodiments of Elizabeth I) combat their commodification through their refusal to marry and fulfill the prescribed gender role.

The third and final chapter, "Performing Power: Queer Virgins in Keats's Poetry” will look to Keats's poetry to reexamine the ways in which the queer virgin dismantles ideas of heteronormativity. The masquerade becomes a function of the virgin that feminist theorist Theodora Jankowski termed "queer" in their challenge to marriage, gender dichotomies, and patriarchy itself, ultimately representing Keats’s own concept of "negative capability.” 


\section{CHAPTER ONE}

Shakespearean Daughters in Transsexual Masquerade

Mary Ann Doane suggests the power of masquerading lies in its ability to denaturalize sexual roles and reveal femininity as a culturally constituted performance (3). The masquerade is an exaggeratedly theatrical display of femininity, thereby holding as a farce that which you flaunt. The daughters in Shakespeare tweak the masquerade on a phallic axis; instead of lacking it, they flaunt its symbolic implications of power and control. Parallel to the female masquerade, "masquing the phallus" implies that gender is grounded not in the body but in performance — hence not convincingly "grounded" at all.

Without becoming too entrenched in questions of authorial intention, we might ask how Shakespearean daughters fare after masquerading. While compliant daughters remain unscathed, as with Bianca and Miranda, daughters who have defied or deposed their fathers in one way or another are ultimately forced into submission, like Katherina, or else meet their tragic end, as seen with Cordelia, Goneril, Regan, Desdemona, Juliet, et cetera.

The Taming of the Shrew is a prime example of the performativity inherent in gender relations and the new husband's transition from male suitor to father figure. At the outset, Katherina is quick to strike, both verbally and physically. She asserts her position over all others and rails when offended but is never defied. Her father asserts his preference for Bianca and Katherina displays a deep-seated jealousy that belies her inner turmoil as she struggles with her oedipal tendencies. Petruchio comes to represent the Law for Katherina as her father is rather mild-mannered in his alienation from but never domination over Katherina. Capable of domesticating the "hawkish” Katherina, Petruchio 
molds her into a "house Kate" by reducing her in no uncertain terms to an inhuman object. He intends to "kill" her with feigned "kindness" (4.1.193) such that keeping her starved and restless is really an endeavor to please her. These conditions, he wagers, lead to the breaking of Katherina's spirit and forces a proclivity to training, a training that resembles the father's disciplining of the child. Petruchio takes on the role of the father as he introduces consequences for her failure to repress her desires. Just as in the Symbolic order, the father forms the triangle, thereby cutting the symbiotic bond between mother and child. The child understands they must separate from the mother and repress their desire to be one with her instead of a sexualized individual. With the mother, the child is in a utopian state of being in which s/he is asexual and thus has no identity. For what is identity without the prescribed performance of gender?

Critics of the play ascribe to one of two sides: it either represents a reification of marriage as a male-dominated institution, or it stands as an intentional parody of it. The latter lends itself to the performance theory where Katherina, although not in power, is in control of the power. She is in control insofar as she plays Petruchio's game, and therein Shakespeare parodies the gender roles within the institution of marriage. This optimistic perspective holds sway over many critics, but it eludes the question: "what choice does Katherina have but to play?” The alternative with Petruchio was to suffer (or die from) starvation, insomnia, and animosity. Even without Petruchio, Katherina faced endless scorn from family and society. Finding herself trapped, she takes control by becoming a player in the game of marriage. A mere two scenes prior to her feminine masquerade, Katherina desperately cries: 
My tongue will tell the anger of my heart,

Or else my heart, concealing it, will break;

And rather than it shall, I will be free,

Even to the uttermost, as I please, in words. (4.3.77-80)

The focus on language as a means to assert one's independence is not stifled, yet many believe reversed in ironic fashion as Katherina advocates female propriety in her usual eloquence and fervor as she concludes the play.

Katherina struggles to obtain what Riviere terms the subject status with language, as opposed to the object status to which Shakespeare allows a paltry line or two. Under the semblance of the perfect wife, she takes control of language that empowers her to initiate discourse, instead of her usual defensive and pithy retaliation. Katherina influences and awes her audience with her moving soliloquy, the longest in all the play. Although in feminine masquerade, she is nevertheless emboldened as subject; as a user rather than a victim of signs. By taking control of language under the guise of femininity, she has paradoxically asserted her transcendence of gender insofar as she performs male expectations of femininity to serve a female agenda. Katherina's last speech of unequaled length is itself an indicator of her appropriation of power, and gives us leave to consider her tremendous turn of values, albeit presumably duplicitous. Katherina transforms from fiercely uncompromising shrew to dutiful wife. There is a comparison developed throughout of husband to wife as sovereign to subject. Petruchio begins it in 5.2.119: "An awful rule, and right supremacy...” as in the awe-inspiring domination of the husband over his wife, and is furthered with Katherina's final speech. She incites the women at the gathering to think of their husbands as "thy head, thy sovereign" (5.2.156), and that wives 
owe "such duty as the subject owes the prince" (5.2.165) as they "are bound to serve, love and obey” (5.2.174). After her soliloquy, the men stand in reverent awe of what Petruchio has bred in Kate. Vincentio and Lucentio create an equation of fathers' daughters and husbands’ wives. Vincentio starts with: “’Tis a good hearing, when children are toward,” and Lucentio responds with: "But a harsh hearing, when women are froward” (Italics added, 5.2.193-194). The parallel syntax illustrates the equating of children with women, in particular, married women. Vincentio and Lucentio complete the analogy of man to wife as sovereign to subject and father to daughter. The wife/subject/daughter must be obedient, never willful and mutinous towards the husband/sovereign/father, as it is the law of the father that must discipline the unruly child-woman for the benefits of patriarchal society.

Katherina’s psychological transformation is reminiscent of Cordelia's as they both commit to honesty at whatever cost yet masquerade womanliness in the later acts. Crucial to their characterization, they share a focus on language as a means to truth. Although their positions on the value of words oppose, both women share the end-goal of honesty. Katherina tells her new father-husband that words are all she has to "tell the anger of her heart” while Cordelia tells Lear she need not prove her love with words. Cordelia is here referring to false words, words that disguise what truly lies within. Cordelia values the unspeakable truth of actions over idle words while Katherina's words are true to her emotions. Katherina was finally allowed her words, though they became a mockery of her dignity. If we are to concede to the view that Katherina is in control of Petruchio’s game, then we must also accept her final speech as dripping with secret sarcasm; dropping her commitment to honesty as an attempt to achieve some shred of 
autonomy in this game where men make the rules. As the audience, we grudgingly accept the suggestion of Katherina's control; otherwise this play would not fit into the comedic canon. As Penny Gay observes, “cruelty can be funny” (86), as long as everyone approves and you remain an untouched spectator. The Shrew's enactment of the phallic power struggle remains light because of our blissful acceptance of Katherina's donning of the feminine mask as the "natural" end. Would our blithe perception be shattered if she had outright forfeited Petruchio’s game? Would Shakespeare respond to the forfeit by writing her tragic demise? To enter into discourse is a privilege. To be heard is to be respected. But the tragic irony behind Katherina's actions is that she only is heard/respected when she says what others want to hear. Reading this play under a queer framework, it becomes increasingly clear that it is far from being a comedy. Even if we subscribe to the view that she has agency in "playing the game," it is still Petruchio's game she is playing.

As Katherina and Cordelia make clear, it does not pay to be honest. Desdemona’s downfall in Othello can only reiterate this message Shakespeare seems to be sending. Defying her father from the first and insisting upon her loyalty towards her husband showed a frankness only rivaled by Cordelia. Just as Cordelia confronted her father's vain sport, Desdemona challenged her father's authority over her not only with her elopement but later in her assertion that her love was not exclusive to her biological father. The better part of her love and devotion was reserved for the man who was much older than her and told her stories of conquest and violence, embodying thus a stronger father than her first. Othello represented a powerful difference rooted in his phallic presence that Desdemona lacked and longed for. Desdemona’s refusal to masquerade 
either femininity or masculinity asphyxiated her continued existence in her male-centered world. By rejecting her first father in favor of her second, she also rejected the first's protection and sought her own means to happiness, thus refusing to play the role of the maiden in need of rescuing (feminine masquerade). Her second mistake was in not taking a more active role in her own defense, but simply hoping her "noble lord esteems [her] honest” (4.2.67). Under the masculine masquerade, she would have taken a sturdy stance against the accusations heaved at her knowing them to be false. A Christian belief in salvation through honesty and forgiveness lulls her into trusting that truth itself will acquit her: "God me such uses send/ Not to pick bad from bad, but by bad mend" (4.3.100-101). Desdemona's final words reaffirm how her failure to masquerade and fidelity to the law of the father led to her fatal smothering:

DESDEMONA. A guiltless death I die.

EMILIA. Oh, who hath done this deed?

DESDEMONA. Nobody. I myself. Farewell.

Commend me to my kind lord. Oh Farewell! [dies] (5.2.121-24)

Yet Desdemona's failure to masquerade is not her only downfall; her adherence to the law of the father is never broken, simply reimagined. As a result, she fits perfectly into the fabric of commodification. In the pivotal scene where she must choose her allegiance—-she has but two choices, her old father or her new one. When Brabantiowith pompous self-assurance—calls upon her to “...perceive in all this noble company/ Where most [she] owe[s] obedience,” (1.3.178-179) Desdemona gives him quite a turn: ...I do perceive here a divided duty...

I am hitherto your daughter, but here’s my husband, 
And so much duty as my mother showed

To you, preferring you before her father,

So much I challenge that I may profess

Due to the Moor my lord (1.3.181, 185-189).

As with legal precedence, she calls upon her mother's choice to disavow an old father for a metaphorical new father as justification. By invoking a rationale so near and dear to Brabantio’s memory, Desdemona hopes to defend her place in the gender dynamic that has existed for generations. With much resentment and resignation at the futility of his platitudes, Brabantio tells Othello that he may take ownership of that "jewel” (1.3.195) he already has: "I here do give thee that with all my heart/ Which, but thou hast already, with all my heart/ I would keep from thee” (1.3.193-195). This only furthers the analogy of a property transaction, only in this case it has not resulted in "profit" for the original owner, nor was it given willfully. But Brabantio manages to inject the venom of patriarchal law into Othello before adjournment, warning him, "Look to her, Moor, if thou hast eyes to see;/ She has deceived her father, and may thee” (1.3.291-292). This aphorism makes a reappearance with none other than Iago in Act Three, when, as proof that Venetian women are not to be trusted, Iago reminds Othello that Desdemona "did deceive her father [by] marrying [him]” (3.3.210). Thus is the parallel drawn: a maiden's obedience to her father becomes her fidelity to her husband.

Emilia’s symbolically masculine masquerade as antithesis to Desdemona's feminine one, bears mention. With her unapologetic quips in stark contrast to Desdemona’s constant naiveté, Othello might very well have been a comedy had Emilia been the female lead. Her irreverent attitude toward marital monogamy underscores her 
recognition of the inequality behind gender relations.

DES. ...tell me, Emilia-

That there be women do abuse their husbands

In such gross kind?

EMI. There be some such, no question.

DES. Wouldst thou do such a deed for all the world?

EMI. Why, would not you?

DES. No, by this heavenly light!

EMI. Nor I neither, by this heavenly light.

I might do 't as well i' th' dark. (4.3.60-64)

By shedding comical light on an offense punishable by social disgrace and even death, Emilia masks feminist commentary with parody. She goes on to reason with Desdemona, taking the latter's words on a literal basis, saying the whole world is more than enough compensation for cuckolding her husband. But all this comic relief comes into perspective when, in her lengthiest part, Emilia reveals the more somber power structure behind her joking. She reaffirms there are multitudes of women in the "world they played for” (4.3.81) just like her. Unlike Desdemona, who blames every father and husband's ill on herself, Emilia is quick to recognize fault in the opposite sex, if deserved: “...I do think it is their husbands' faults/ If wives do fall...Why we have galls, and though we have some grace,/ Yet we have some revenge. Let husbands know/ Their wives have sense like them...Then let them use us well, else let them know,/ The ills we do, their ills instruct us so" (4.3.82-83, 88-90, 98-99). In one of the rare occasions where a Shakespearean female character directly problematizes the marital institution as a 
structure of power, Emilia trumps the need for a masculine masquerade, instead standing as a woman, holding men as her equal in all things.

The Merchant of Venice (MOV) also serves as a paradigm for the thematic strains of this discussion: the marital economy at the virgin's expense and the phenomenon of the masquerade as a woman's self-typecasting or empowerment. With $M O V$, Shakespeare explored the idea of capital—both monetary and of the flesh. Venice emerges as a “mercantile world” (Crawford 1) where the inhabitants risk everything for profit-in life, love, and marriage. A “pound of flesh” might be worth less monetarily than a pound of beef, but its symbolic worth is tripled in pride and vengeance. Thus is flesh extracted for reasons of conquest and sacrifice-Shylock wanted to conquer over the Christian Antonio, while Antonio was willing to sacrifice his flesh for the love and loyalty he bore to Bassanio. Similarly, Portia is willing to give her body, soul, and wealth to Bassanio with only the profession of his love in return. Given his impoverished (indeed, indebted) condition, Portia’s eagerness to give herself and her dowry is quite the sacrifice, a model of the feminine masquerade. Perhaps this is why she rebukes him so harshly when she later learns that his commitment is not as unwavering as hers. This occurs in the trial scene as well as upon Bassanio’s return, and will be developed further in our discussion of Portia.

Shylock’s daughter Jessica, just like Antonio, rejects the idea of free market enterprise and competition when she "literally tosses [Shylock's] money from his house and exchanges his wife’s ring for a monkey” (Crawford 4). In Act Two, Solanio mocks Shylock’s public grieving: “'My daughter! O my ducats! O my daughter,/ Fled with a Christian! O my Christian ducats!'” (2.8.15-16). Here his fortune and pride are doubly 
bereft, since both human and monetary possessions are in the hands of a Christian. His dismay at losing both items seems to be in equal parts. Later however, the way in which Shylock refers to Jessica is objectified and monetized at a very low value: "I would my daughter were dead/ at my foot, and the jewels in her ear. Would she were/ hearsed at my foot, and the ducats in her coffin!” (3.1.77-79). It is as though her elopement and betrayal — with a Christian of all men—in addition to the time passed, has added to her depreciation.

The character of Portia appears as a paradox: she is all at once "a rich heiress and a 'learnèd doctor,'” as such, a “desirable commodity and an active agent” (Crawford 1). Of course, she only becomes the active agent when she masquerades as a man, transforming seamlessly from an "unlessoned girl, unschooled, unpracticed" (3.2.159) to what even Shylock calls a "wise and upright judge" (4.1.248). In spite of this initial masquerade, there is some foreshadowing of Portia's cunning resourcefulness, by her own admission: "She is not bred so dull but she can learn" (3.2.162). And yet, she submits herself to her future husband, "her lord, her governor, her king” (3.2.165). This alludes to domestic conduct books of the time as well as the bible, Ephesians 5:22, which commanded: "Wives submit your selves unto your husbands, as unto the Lord" (Crawford 168). The language of property abounds, as she describes her entire self as Bassanio's, cursing the "naughty times/ [that] puts bars between the owners and their rights” (3.2.18-19). In this scene they anxiously await their marital fate as dictated by Portia's dead father, who even in death exerts his will upon the transaction of her marriage. Upon opening the correct casket, Bassanio is beside himself to "give and to receive” (3.2.140) the kiss that signals marriage, as per the scroll, and yet must wait 
"until confirmed, signed, ratified by [Portia]" (3.2.148). Though metaphorical, the diction clearly suggests contractual language. Furthering the idea of flesh property, Portia describes herself to Bassanio as the "full sum" (3.2.157) that is being willingly handed over.

Portia seals her vow of commitment with another material commodity, a ring, but here she begins her "masculine” masquerade. If Bassanio loses or gives away this ring, Portia warns, "Let it presage the ruin of your love/ And be my vantage to exclaim on you” (3.2.173-174). Thus, with all she gives, she also requires. This deal, very businesslike and bold (since she announces her right to revoke her love) has a stereotypically "masculine" awareness to it. During the trial scene in Act Four when Bassanio asserts his readiness to sacrifice anything —including his wife — to save Antonio, it is a shrewd Portia/Balthazar that replies, "Your wife would give you little thanks for that/ If she were by to hear you make the offer” (4.1.286-287). This is paralleled by a similar exchange between Gratiano and Nerissa. Only donning the habit of men can Portia and Nerissa hear the truth about where their husbands' loyalties lie. Given her disappointment, it is with considerable irony that Portia tells Bassanio, "I pray you know me when we meet again” (4.1.417). As another test, she asks for the ring as compensation. When Bassanio initially refuses, Portia/Balthazar shames him for holding out and mocks his wife as being a "madwoman" (4.1.443) if she could not understand how well deserved the gift would be. Finally, it is Antonio's pleading that convinces Bassanio to do away with his marital oath: "My Lord Bassanio, let him have the ring./ Let his deservings and my love withal/ Be valued 'gainst your wife's commandment” (4.1.447-449). With this ironic reversal of deserved allegiance, Shakespeare undoes the laws of patriarchal devotion. Though it is 
thanks to none other than Portia that Antonio lives, Bassanio fails his vow to her and chooses to pay his respects to the men in his company. Whereas prior to his departure she had described her and Nerissa awaiting their husbands like "maids and widows," (3.2.309) in the final scene she counters Bassanio’s inconstancy with the threat of sexual license, having no qualms about teaching him a lesson in reciprocity. Portia becomes even bolder in her masculine masquerade, threatening to punish Bassanio for his disloyalty by "becom[ing] as liberal as [him]," (5.1.226) with "liberal” not-so-subtly meaning lascivious: “I'll not deny him anything I have,/ No, not my body, nor my husband's bed...Pardon me, Bassanio,/ For, by this ring, the doctor lay with me” (5.1.227-228, 258-259). Nerissa also joins in the fun: “And pardon me, my gentle Gratiano,/ For that same 'scrubbèd’ boy, the doctor's clerk,/ In lieu of this, last night did lie with me” (5.1.260-262). Their willingness to mock their husbands on such serious grounds reveals the overall unraveling of the marital institution as sacred bond of trust. $M O V$ satirizes a number of establishments and dynamics: the transaction of marriage, inner versus outer worth, perception of real versus imaginary, and so on. In terms of inner versus outer worth, we have the three caskets as the ultimate manifestation of the Law of the (Dead) Father and Portia's stunted existential capacity as a woman. The casket with the least outward value contains the highest inward value, since it taps into Portia's dowry. It is only after the law of the father is served, when Bassanio chooses correctly, that she is no longer beholden to it and declares herself (and her wealth) at her new husband's disposal. It is after this point that she adopts a more autonomous persona that defies her original gendered characterization. Jessica's, but especially Nerissa and Portia's masquerades, expose the relativity of gendered behavior. What was assumed 
impossible for a woman is made possible when Nerissa, toying with her husband's perception of the truth in the final Act, tells him "[t]he clerk will ne'er wear hair on 's face that had [the ring]," and when he replies "He will, an if he live to be a man," she concludes, “Ay, if a woman live to be a man” (5.1.158-160). Little does he, or Bassanio, know that both Nerissa and Portia have lived to be men, and women, saving the day as such. So even though prior to their cross-dressing, Portia had said to Nerissa "they shall think we are accomplished/ with that we lack," (3.4.61-62) it seems these women have more than their husbands bargained for. Barring this comical reversal of roles, however, taking a closer look at the homosocial (to borrow Sedgwick's term) bonds of the playPortia in league with Nerissa to expose their husbands, Bassanio and Gratiano showing ultimate loyalty to Antonio, the "male" lawyer and his clerk—only reaffirms that women are not viewed as equals, however much they "play" at it.

Karen Newman argues that the merchant ship’s feminine personification [“...of dangerous rocks/ which touching but my gentle vessel's side/ with scatter all her spices on the stream" (1.1.30-34)] hints at both the commodification and exploitation of women in the play. She cites Marcel Mauss in saying that, "food, women, children, possessions, charms, land, labor, services, religious offices, [and] rank," all function as part of an exchange system (253). She furthers this idea by referencing Claude Lévi-Strauss as reworking Mauss' theory to include heterosexual marriage as being the capstone of all gift exchange, with women as the ostensible tokens (253). She quotes Lévi-Strauss: “The total relationship of exchange which constitutes marriage is not established between a man and a woman... but between two groups of men, and the woman figures only as one of the objects in the exchange, not as one of the partners...” (Newman 254). As Newman 
tells us,

Such a sex/gender system functioned historically in early modern England where marriage, among the elite at least, was primarily a commercial transaction determined by questions of dowry, familial alliances, land ownership, and inheritance. Daughters were pawns in the political and social maneuvers of their families, particularly their male kin. Marriage contracts and settlements, familiar letters and wills, conduct books and sermons alike recognize in marriage an economic transaction based on the exchange of gifts—-women, cash, annuities, rents, land (257).

The authority of the patriarch becomes abundantly clear when considering that even in death, Portia's father was still in posthumous dialogue with the suitors. While we recognize her entrance into the male-dominated realms of Venetian law and politics, we must also recognize her exit. Although "In giving more than can be reciprocated, Portia short-circuits the system of exchange and the male bonds it creates...” (Newman 261), ultimately, Portia’s role reversal and subversion is temporary. Many Shakespearean feminist critics, like Newman, argue that comic heroines committing this transgression remain conservative in the sense that the cross-dressing is done in the service of courtship and eventual marriage. Though she has simulated male privilege, the Shakespearean comic genre dictates that all revert back to a harmonious status quo—-male hegemony (264).

Turning briefly from the texts back into our theoretical framework, we have seen how some daughters in Shakespeare adopt the female masquerade as a means to acceptance: to become the object of desire for the men in their lives. Finucci describes the 
willful manipulation of men's sexual responses to be a tool that empowers women and at the same time reveals femininity to be a mere construct (82). This puts into question the rules of gender: if femininity is not an innate characteristic but instead a performance (or masquerade), then the same can certainly be said of masculinity.

In his earlier stages, Freud believed masculinity to be the archetype of sexuality, saying that there is no such thing as femininity, rather, only one libido — the masculineand femininity can be upset at any point in time by the resurgence of the latter (Finucci 65). Women who masqueraded as men were viewed as a threat in their assumption that they could partake of phallic privileges. Finucci insists that adopting a male psychology (or a sense of male agency) is much more subversive than a rudimentary disguise (64). In As You Like It, Rosalind does both.

Telling is Rosalind's decision to upgrade herself in terms of gender hierarchy by becoming a “man,” and it seems to enhance her confidence, while Celia takes the backseat. Her choice of namesake and persona is also significant as she later tells Phebe she can never love another woman. Ganymede as Zeus’s cupbearer and boy lover would certainly fit the homoerotic orientation, so Rosalind has shrewdly created an alternate character that also reflects her sexuality. Rosalind relishes her psychological and physical disguise, inventing her own identity before submitting herself to male conquest. As Ganymede, her near omnipresence as a stage manager belies a masculine subject status similar to the roles of Iago or Hamlet. Defying his/her own assertion that "it is not the fashion to see the lady in the epilogue” (Epilogue 1-2), Rosalind's presence rather than absence in the epilogue shows the fluidity of the boy actor who comes full circle in his entire performance. This male player says, "If I were a woman, I would kiss as many of 
you [men]" (Epilogue 16-17) while playing the heroine who in turn disguises as a boy. Rejecting essentialist binaries, Rosalind's performance in either gender is never fully developed. While she revels in phallic privilege, she often reverts to her "female nature," although this femininity is arguably another performance. She breaks into tears, is lovesick, and rambling. Full of "womanly" pathos, she tells Celia her affections "take the part of a better wrestler than myself!”(1.3.22-23). Later in Arden, she swoons over the news of Orlando's injury, and quickly regains her masculine mask by insisting she “counterfeited” (4.3.136).

In contrast, she is able to perform masculinity credibility (insofar as expectations go) with her disparagement of women and skepticism of true love. Her purpose in wrecking the female "nest" is twofold: develop rapport with her equal male friend and test his true inclinations on women and marriage. Ganymede warns him of the disastrous changes upon getting married and parrots male expectations of femininity, citing women as jealous, prone to idle chat, shallow, wanton, fickle, and irrational:

...men are April when they woo, December when they wed. Maids are May when they are maids, but the sky changes when they are wives. I will be more jealous of thee than a Barbary cock pigeon over his hen, more clamorous than a parrot against rain, more newfangled than an ape, more giddy in my desires than a monkey. I will weep for nothing, like Diana in the fountain, and I will do that when you are disposed to be merry; I will laugh like a hyena, and that when thou art inclined to sleep. (4.1.137-146)

Portraying women this way allows Rosalind to be Orlando's equal and extract honest information unhindered by the pretenses of heterosexual courtship. 
Fathers are ubiquitous in Shakespeare, as a woman moves from being the father's child to being with the child's father. Rosalind begins the play mourning over her father's banishment, yet speedily makes the transition towards her new father. After she first beholds Orlando, her anguish is divided between her banished father and her "child's father” (1.3.11). Later in the forest, her loyalties are once again given to her prospective rather than biological father: "but what talk we of fathers when there is such a man as Orlando?” (3.4.35-36). When she encounters her father in the forest, she resists exposure as this would mean once again placing herself under his protection and thus limiting her newfound independence under the male masquerade. By delaying her exposure to Orlando, Rosalind creates a space between the detachment of her father and the attachment of her new father, between the "giving away" and the "taking," that suspends her conquest and allows her freedom, albeit temporarily. The wedding scene is the correction of all homoerotic "folly" and the characters must settle the immature obfuscation that has run rampant in Arden. Hymen makes this clear with his interjection, "Peace ho! I bar confusion: / 'Tis I must make conclusion/ Of these most strange events...” (5.4.123-125) and so seals the bonds of heterosexual marriage, a necessary institution for the order of patriarchal civilization. Marriage also brings Rosalind's resubmission into patriarchal object status:

ROSALIND. Keep you your word, O Duke, to give your daughter;

You yours, Orlando, to receive his daughter...

(To the Duke) To you I give myself, for I am yours.

(To Orlando) To you I give myself, for I am yours. (5.4, 19-20, 114-15, italics added) 
Both Orlando and Rosalind shun honesty in favor of performing playful gender negotiations where the distinction between homo and hetero-eroticism is never clear. The bond between Orlando and Ganymede serves as a brilliant parody of the heterosexual institution of marriage as well as any notion of inherent sexuality. Rosalind is able to shatter the binary opposition in which she is inferior and thus forms a friendship where both parties are in equal standing, man to man. Although Rosalind finally strips down to her anatomy, relinquishes power, and capitulates to both father and husband, she has imprinted an indelible uncertainty in the social network of her time. She reveals that sexual identity is nothing but a fluid construct apt for the manipulation of women who refuse to be castrated and marginalized.

Yet not all daughters in Shakespeare masquerade as successfully as Rosalind for their personal gain. As is sometimes the case, the father plays a more pivotal role. Returning to the idea of the father-daughter bond being one of possession and control on the father's part, rebellion or surrender on the daughter's part, we note the interaction between Prospero and Miranda in The Tempest. Miranda never willingly detaches from her father, she is expressly — and with trial and tribulation on Ferdinand's part—given away. After Prospero has debased Ferdinand to arduous labor fit for a slave and assured his connections with nobility, he relinquishes his hold of her. Miranda is made into a commodity where her value is directly related to her virginity:

PROSPERO. I ratify this my rich gift...

Then, as my gift and thine own acquisition Worthily purchased, take my daughter. But If thou dost break her virgin-knot before... 
Sour-eyed disdain, and discord shall bestew

The union of your bed with weeds so loathly

That you shall hate it both. $(4.1 .8,13-22)$

Miranda is the desirable virgin owned by the father and catching the fancy of an extraordinarily eligible bachelor. It is not altogether certain whether Prospero induces the love connection or it is formed independent of magic, but the union is an extremely favorable trade for the ambitious patriarch. So after Ferdinand "strangely stood the test" (4.1.7) that Prospero gives him to assess his commitment, Prospero makes the exchange. Without the intactness of the hymen, the agreement between both parties would be null and void, rendering Miranda materially worthless.

The patriarchal order and sexual economy seems to invariably reestablish itself, as we see with The Tempest. When Prospero and Alonso meet in the last scene, Prospero tells Alonso that he has lost a daughter; as if she no longer existed now that he is no longer able to say she belongs to him, but to Ferdinand. Ferdinand and Miranda's chess game in the last scene is metaphorical of the political maneuvers involved in the institution of marriage, the father's ownership of the fleshy goods, and the transfer of ownership to the husband as new father. Here is where Ferdinand beholds his father again and tells him of his joy in Prospero's gift. Ferdinand says he has “received a second life from him” (5.1.195) and Alonso claims to have become a second father to Ferdinand's “second life,” Miranda, as Prospero became the new bridegroom’s.

This late tragicomedy has far-reaching implications into post-colonial as well as feminist theory. The Miranda-Prospero, Ariel-Prospero, and Caliban-Prospero dynamics all unify the central patriarch of Prospero. His treatment of daughter, spirit, and slave are 
not as distinct as they initially appear. Prospero’s enslavement of others defines his identity as the powerful monarch of the island in contrast to the abject weakness of his subjects. He releases everyone once his own ends have been secured: title, status, respect. He releases Miranda after he tests Ferdinand's devotion and secures his filial dynasty in Naples. He releases Ariel after it has done his bidding, Ariel tirelessly weaving an undetected web of magical confusion. He releases his inland relations after they have professed their remorse and Prospero's reinstatement as Duke. Finally, he releases Caliban from the prospect of eternal torture when Caliban willingly submits himself to enslavement: “...I’ll be wise hereafter/ And seek for grace...” (5.1.294-95). Caliban’s enslaved condition and subsequent lack of phallic power despite his anatomical gender is in stark contrast to Prospero and thus defines Prospero as patriarch. As Caliban is sullied and abused, he is also necessary. Prospero insists to Miranda that "we cannot miss him. He does make our fire, fetch our wood and serves in offices that profit us” (1.2.313-15). This statement of reluctant dependence reminds us of the parallel of sovereign to slave and man to woman, as in phallocentric culture the man's identity of power is defined by its binary opposite, the weakness of woman.

Ariel as an explicitly un-gendered yet performative female completes Prospero’s patriarchal supremacy. When Ariel, the androgynous "airy spirit” stakes a claim for promised freedom, Prospero employs a similar tactic that he uses with Miranda, a sort of “good father/good master” routine. With Miranda, he recounts their escape from Milan and his subsequent caring for her. He was her first "schoolmaster" (1.2.172), her first lover, and her first masculine paradigm. He presents himself to his subjects in a wonderfully favorable light as their savior. Prospero describes the horror of Sycorax’s 
torturous imprisonment of Ariel and reminds the spirit that it was he who rescued it. Ariel responds in a surge of gratitude and Prospero quickly reverses the tide and threatens to trap the spirit inside an oak tree if this mutinous behavior arises again. He adds that if Ariel does his bidding diligently and without question, he will set it free in just two day's time. Ariel fearfully begs pardon and eagerly asks for assignment. The exchange suggests Ariel's feminine identity in its inferior object status and exploited condition. Prospero’s treatment of all his subordinates fit a cycle of either accusations or threats followed by calls to gratitude. First he accuses Miranda of not listening to his self-righteous account of his dismissal from Milan, then tops the tale off with his continued sacrifice for her safety and well-being. As we have already seen, he accuses Ariel of gross ingratitude, threatens it with the selfsame torture he saved it from, and obtains a guilt-ridden submission. Prospero’s self-serving exchange with his feminine subjects illustrates the patriarch’s dependence on his inferiors while highlighting the uneven scale of power. Without Ariel's laborious efforts, Prospero could not have enchanted the entire shipwrecked host. Similarly, without Miranda, he could not have secured a connection to the throne in Naples. Where would Prospero be without either feminine subject? The dependence is not immediately felt, but with a bit of prodding, unquestionably there.

Whether a politician like Katherina, a transsexual like Rosalind, a pawn like Miranda, or a tragic victim like Desdemona or Cordelia, a Shakespearean daughter must respond in her own way to the phallocentric institution that commands her existence. For the surviving daughters, this means donning a mask that allows the wearer to compete in the phallic-dominated game of their time. If the hierarchical binary cannot be undone, 
resourceful daughters will find a way to cheat in a game that was rigged from the moment they laid eyes on the father. 


\section{CHAPTER TWO}

Spenserian Virgins: The Repudiation of Marriage and Perpetuation of Power

Moving from Early Modern drama to poetry, we question the origin of the virgin as the paradigm of unspoiled beauty as it appears in selections of Edmund Spenser's work. Looking closely at Books III and IV of The Faerie Queene, it becomes clear that this paradigm of purity has been propelled by patriarchal mores, extending as far as the institution of marriage and the gender roles implied therein. For Spenser, marriage effectively transformed the idea of chastity into the Protestant ideal of married sensuality, relinquishing the woman's will to the husband in her complementary yet fundamentally unequal role. This power hierarchy is still ubiquitous in many religious institutions today, most notably Catholicism, which, by continuing to practice complementarianism, further relegates women to support roles while men remain in leadership roles.

In these leadership roles, men can continue to assign values to the anatomical conditions of a woman, creating the polarized, yet equally destructive roles of "virginal pawn" or "sullied whore”. These are the harrowing options left to women under Elizabethan (and current) misogyny, though Dympna Callaghan would argue that "'woman' is never an already accomplished, cold, hard, self-evident fact or category, but always a malleable cultural idea as well as a lived reality that, to use a Derridean formulation, always already has a history" (xii). To illustrate the historicity of the terms used to define women, she explains that the word "whore" has a long history (and even contemporary usage) of patriarchal oppression attached to it-whether uttered by men or women. Indeed, what ensures the perpetuation and apparent viability of the patriarchal order is that many women, "no less than men" (Callaghan xiii) re-present and reinforce 
the politics of violence. It is elemental to the self-sustaining nature of patriarchy that women engage in their own debasement. The hurling of such an insult had material ramifications for women of the late 16th and early 17 th centuries, resulting in disownment by those who held the position to provide economic support. The word then, transcends denotation and becomes a signifying structure on a physical, rather than just emotional, scale.

As seen in Spenser's Epithalamion, there is a natural curve to a woman’s worth, with the parabola inextricably linked to marriage. The ascent is closely tied to youth and virginity, the apex being the moments before her deflowering, and the descent as becoming a wife and mother, bereft of virginity's unspoiled perfection. Indeed, the word "virginal" supplied to any dictionary search engine yields synonyms like "pure," "unsullied," "untouched,"'fresh," "undefiled," and the like. Likened to the modern experience of driving a new car out of the dealer's lot, the material valorization of the woman in Elizabethan culture was as such: commodified. Spenser considered poetry the highest form of regard for another, on many instances describing it as a means to defy death. Yet scarcely was a poem written singing the praises of the dutiful housewife and mother while the maiden was often the subject/object of poetic verse. The maiden comes to represent that phallic ideal that man covets while not in his possession. The beauty is in the chase; the unattainable quality of the immaculate virgin spurs men to action, and in Spenser's case, to writing poetry. The chaste and thus powerful female characters were even fain to choose death over rape. Preserving the symbol of their independencevirginity — was also a means of maintaining agency in and out of "Fairy Lond.” As such, power was intimately tied to both sex and text—-the maiden was an indelible part of the 
literary canon. Some characters seemed to be more aware than others of that notion, best illustrated by the elusive Gloriana or Florimell, whose honor becomes synonymous with the hymen, culminating to a matter of divine intervention in Canto VIII of Book III when the fisherman was a hair's breadth away from defiling her.

Here we turn to the gender dynamic during Elizabeth's reign, which was in many ways singular in terms of its stress on feminine virginity as power. Elizabeth invariably placed her head above her heart in matters of the state and the obligations of sovereignty. When the time came for her to renounce or otherwise share her power with Robert Dudley, she took a knife to the Letters Patent and made public his humiliating rejection. As if to add insult to injury, she patronizingly patted his cheek and told him not to worry about the fate of his family crest, for they would not be so easily discounted, though she had done just that to his dignity with a mere swipe of her wrist (Weir 114). On numerous occasions, often in deliberately public spectacles, she asserted her impenetrability both as a maiden and as a monarch. "The Virgin Queen” was to become her calling card, to the ill-concealed envy of many ambitious members of court with aspirations to the throne. It seems she was privy to the charm of the unattainable, as was Canacee in Book IV of the Fairie Queene: "So much the more she refusd to love,/ So much the more she loved was and sought,...” (IV.2.37). Likewise did Elizabeth eschew the kind of love that would expose the symbol of a woman's enigma and therefore control: the maidenhead. Berger relates this concept to the Queen by adding that the sheer unknowability of the woman as the object of yearning makes the issue of virginal power even more influential in Book III, known as the Book of Chastity (94). He calls this power "dangerous not only to men who are overthrown by chastity's spear or undone by beauty's chase but also to those who 
suffer the ignominy of having to be saved or replaced by the fearless woman warrior" (94). He refers here not only to the female characters that protect their chastity through flight, but to the one and only that resolves to fight, Britomart. She stands in blatant contrast to all other feminine figures—both chaste and not—insofar as she mounts an offensive rather than defensive mode of being, highlighting her masculine agency within a feminine anatomy.

It would seem intuitive then that the most powerful women in Spenserian works emerge as either impossible to possess (as a testament to their virginity), indeterminate in their sex, or both. Attesting to the first model would be Florimell and Belphoebe; Britomart being the obvious choice for a combination thereof. In Book III, Britomart emerges as an androgynous character whose power, beyond the enchanted spear and martial prowess, lies in her ability to masquerade as either feminine or masculine. She adds tension to the gendered power dynamic that exists inside and outside of the text, including Spenser and Queen Elizabeth. As the clear choice for rejecting binaries of sex and sexuality, she revels in hermaphroditic agency. Anderson describes her as "an armed but nubile virgin, not only Venus-Virgo but also Venus within Mars," (74) making her a "complex cultural signifier" in constructs of gender, eluding an absolute definition as masculine or feminine. Britomart enjoys a fluidity in both sex and text, evincing an unequaled independence in her appearance, actions, and words. She dons armor and shape-shifts into knightly guise so convincingly, that she is involved in many homoerotic situations. For some examples, consider Malecasta's concupiscence in Book III, Amoret's anxiety and Britomart's masculine appropriation of her in Canto I of Book IV, and winning the false Florimell in Canto V of Book IV. Since Britomart has been 
circumscribed by chastity due to her hetero-normative marital love with Artegall, she rejects same-sex venues and yet remains a provocative figure for such thinking. In Canto $\mathrm{X}$ of Book IV, she effectively operates in both realms, with her armor (as physical and immaterial) that

"forms and masks, expresses and veils, protects and contains her...Symbolically, Britomart and Amoret's combined silhouette on a single horse at the outset of Book IV recalls the sexual hermaphrodite in the original ending of Book III and anticipates the statue of Venus with 'both kinds in one,/ Both male and female, both under one name'" (Anderson 74)

And though she remains chaste in her quest for Artegall, she chooses on many occasions to remain a male figure even after danger has past. Even after Busirane's defeat, she objectifies Amoret with all her anxiety over appearing unchaste at the outset of Book IV, for no other apparent reason than her enjoyment in performing masculinity. So invested is she in "vertues onely sake, which doth beget/ True love and faithfull friendship" (IV.6.46), that she remains under the guise of manhood and forgoes a definite future with Artegall, for whom she adopted the mien to begin with. By feigning indifference, she rejects what Spenser would term "womanly modesty" and instead ascribes to a masculine sense of pride that avoids vulnerability. She resolved to "hide her wound, that none might it perceive:/ Vaine is the art that seeks it selfe for to deceive" (IV.6.40). It is after all Britomart that first assigns herself to the mission of finding Amoret, even after learning Artegall's true identity. Despite her assurance to take him as her "Lord," there is an ambiguity in their accord to marry and a sense of finality in what should be their trial separation. Significantly, she decides not to tell him the true goal of her quest. This 
reveals transcendence from the mere feminine character that is acted upon and has a teleological end when married. She opts instead for an androgynous agency where she alters her fate as she sees fit, even concealing her original plan from Artegall in favor of continued knightly heroics. Her new plan morphs into assisting Scudamour in rescuing Amoret. Britomart eclipses the expectations of either sex, rewarding the reader with a sense of release and crediting her creator with the foresight to pen women this waypending the following reservation concerning Florimell and Belphoebe.

Initially, we see Florimell and Belphoebe as the virgins that knights (and lowly squires) could not possess. Much can be inferred about Spenser eventually joining these autonomous feminine figures with men in marital or marital-like monogamy. Could it be a way to re-appropriate the power on the due side of the masculine if we conceptualize marriage as a phallocentric institution? Berger comments that the virgin power is ironically highlighted as a "virtue necessary to male control of marriage, the institutional cornerstone on which the preservation and continuity of patriarchal order are founded" (94). In support of this concept, consider the company Amoret kept in the Temple of Venus before Scudamour came to claim her as his wife: Womanhood, Shamefastness, Cheerfulness, Modesty, Courtesy, and Obedience; all complementary to the institution. This is also strongly supported by Merlin's advice to Britomart when she first embarks on her quest for Artegall: "Submit thy wayes unto his will" (III.3.24). In this "sage" advice, much is revealed: fulfill your destiny as a woman and a virgin by yielding your identity and virtue to your superior.

So, even when creating powerful, autonomous female figures like Britomart and Belphoebe that resonate with Elizabeth and Diana, Spenser does it under what Berger 
refers to as a "Petrarchan dispensation" (96). The vulnerable statuses of Artegall and Timias are countered by the poet's representations of female pride, evoking from the reader a strong sense of camaraderie for the hapless men whom these arrogant, merciless women exploit. Berger contends that the poet is ultimately in control:

Whatever power a Diana figure like Belphoebe has over man is a power ceded by the poets who have power over her in the sense that she is their fantasy. The ideal of the autonomous virgin is a diversionary fiction enabling the male to represent himself as a victim entitled to poetic revenge (96).

We are reminded of Spenser's own voice when he speaks to Elizabeth Boyle through his writing in the Amoretti, at a time when his conquest of her seems precarious at best. Painting a vivid picture of himself as unjustly pained and tormented by her unyielding pride, he makes numerous references to his eternalizing power. This reverberates as a vendetta against her cruelty, so that it would not matter if she does one day accept him. The indelible mark of womanly selfishness will remain on her breast as long as this text endures:

But what this verse, that never shall expyre,

Shall to you purchas with her thankles paine

Faire, be no lenger proud of that shall perish,

But that which shal you make immortall, cherish (AMO.27.11-14).

Adopting a resentful and accusatory tone, he often explicitly blames her for his misfortune and ultimate demise as she adamantly refuses to submit to his will:

Then thinke how litle glory ye have gayned,

By slaying him, whose lyfe though ye despyse, 
Mote have your life in honour long maintayned.

But by his death which some perhaps will mone,

Ye shall condemned be of many a one (AMO.36.10-14)

Yet as he begins to gain her affection, he also gains her subjugation through the male dominated institution of marriage and its attached conventions. Spenser remarks on her "fondly" or foolish fear of "loosing her liberty" upon her acceptance—-the diction indicating his dismissal of female autonomy. In a disturbingly misogynistic metaphor likening women to mindless birds, he comments that "The gentle birde feeles no captivity/ Within her cage, but singes and feed her fill," as though Elizabeth should be glad to have some trifling pastime and food galore within her gilded conjugal cage. The troublesome imagery does not abate when Elizabeth decides to marry him. He responds in arrogant triumph, with a flurry of battle and hunting metaphors that suggest she has been captured, depicting her as the "bee;" a victim of his net, while he revels as the "spyder" in his absolute dominance:

Right so your selfe were caught in cunning snare

Of a dear foe, and thralled to his love:

In whose streight bands ye now captived are

So firmely, that ye never may remove... (AMO.71.5-8)

Successful in his rhetoric, he accomplishes her taming by the Epithalamion, as he eagerly awaits her bedding and subsequent stripping of pride. Elizabeth's once haughty glare that once looked down upon his advances, is now "affixed" upon the lowly ground, her "modest eyes abashed to behold/ So many gazers...," while she dares not lift her gaze and maintains a steady "blush" at hearing her "prayses sung so loud" (EPI.9.161, 159, 
163). Marking the completion of his male dominance is the subversion of Elizabeth's previous identity in what he coolly regards as a foolish love of "liberty." If this can serve as evidence for the claim of marriage constituting a patriarchal construct, then this was Spenser's way of steering the powerful virgins of the Faerie Queene into a masculinegoverned humility that sacrificed all prior subjectivity. Originally set at twenty-four books, we make do with an incomplete account of Faerie Lond, Cleopolis, and its inhabitants. It seems however, that Spenser's idea of satisfactory completion for Una, Britomart, and the other unmarried virgins would have been the same fate that befell Elizabeth Boyle, bereft of power and allegiance-bound to her husband. Gladly would he have Gloriana herself in a similar position, prostrate with humility, eyes fastened to the ground in due womanly modesty. But no matter, for with his words he reestablished the order. Faerie Lond was only a reader away from Queen Elizabeth's England. 


\section{CHAPTER THREE}

Performing Power: Queer Virgins in Keats's Poetry

Using John Keats's La Belle Dame sans Merci, The Eve of St. Agnes, (hereafter La Belle Dame and St. Agnes) and Lamia as points of discussion, we will explore the sexual economy of Keats's time and the fluidity of gender itself. Of particular importance will be the role of the virgin in these three pieces, and how this anatomical state represented both a desire and a threat for the idiosyncratic patriarchal order. While this was the desired (and expected) state for a young woman to be in, it was also assumed to be transient; that a girl should become a woman by moving from virgin to non- virgin, from maid to wife. Men held the privileged role in this gender dynamic, becoming the defining agent via penetration. The idioms and metaphors used to describe the loss of virginity (defilement, deflowering, taking of virtue/honor, etc.) are very telling, since they serve as purely rhetorical agents for a male dominated society. This is the interrelation between sex and text - men have had the privilege (to invoke Toni Morrison) of being the defining agents, whereas women have been the ones defined.

In La Belle Dame, we experience the patriarchal subject's worst fears realized; a woman so alluring and treacherous, she renders the male lover insubstantial. With $S t$. Agnes, we encounter quite the opposite: a virgin that is fully pliant to the patriarchal demands of her body and her agency. This rendering serves to reify the virgin as a commodity within the nineteenth century European gender dynamic, a girl eager to present her future husband with the gift of her "virtue." While Madeline is a proper adherent of patriarchy, Lamia embodies a fascinating combination of guileless virgin and duplicitous seductress. In keeping with such ambivalence, we will also develop an 
understanding of "queer" virgins as those who challenge gender role dichotomies, and as such, become incarnations of Keats's "negative capability.”

Protestant ideals for female chastity played an important role in Keats's conceptualization of the virgin within his poetry. To elaborate on the power of resistant virgins, Theodora Jankowski opens her discussion of what she terms "queer" virgins by presenting the figure of Jeanne d'Arc, or Anglicized, Joan of Arc, as a "dubious virgin, sexually as well as militarily transgressive," and as such, a definite threat to the premises of patriarchy (2). Using this as a departure point, she transitions into early modern British society (the ramifications going well into Keats's time), where a virgin was expected to behave a certain way and defer to her male superiors in a relationship that created a sexual economy. The first proprietor of the virgin was the father, and he would later pass ownership to the husband, oftentimes with economic interests involved. Virginity became a prerequisite, yet temporary biological condition to ensure the intactness of the "goods" before sale. Jankowski describes this as the "fetishization" of the unperforated hymen (4).

A brief expansion is warranted on this definition of "virgin" as a patriarchal construct, since it presupposes a man having to rip through the vaginal membrane in order to move from "virgin" to "non-virgin," or "girl" to "woman." It is the physical crossing of a boundary (the initiating, literally penetrating, and therefore defining agent being a man) that causes the crossing of another, more subjective boundary. Of course, a girl can become a woman in many other ways, including but not limited to sexual relations with another woman with the possibility of leaving the hymen intact. Rupture, with the agenda of impregnation, was the patriarchal definition of "proper" sex, so it's not surprising that women like Joan, who decided to remain virgins (as defined by men) were 
viewed as dangerously queer, irrespective of sexual preference. The understanding of "queer" as it operates here, is not limited to the gamut of non-heterosexual activities, but widens further to "challenge and confuse our understanding and uses of sexual and gender categories" (Doty). It functions as a resistance to heteronormative thinking; as a unique manifestation of sexuality. As Eve Sedgwick employs the term, it is "the open mesh of possibilities, gaps, overlaps, dissonances and resonances, lapses and excesses of meaning when the constituent elements of anyone's gender, of anyone's sexuality aren't made (or can't be made) to signify monolithically " (8).

In daring opposition to this gendered hierarchy, let us briefly consider Shakespeare's Joan from Henry VI as she destabilized the authority of her father (and in so doing, the entire filial ladder that places women on the lower rungs). She was vilified by Shakespeare, making her callously duplicitous and sexually wanton, opposing the commonly held expectations of a virgin for the time: to be "chaste, silent, obedient" (Jankowski 3). Joan's resulting punishment was commensurate not just with transgression, but with the added insult of being a woman committing such transgression. Though Keats generally seems sympathetic towards transgressive virgins, like Lamia, characterizing them as lamentable rather than fear-inducing, their tragic ends seem to foreclose any imitation.

Prolonged, intentional virginity represented a tangible threat to the sexual economy, since the virgin existed in a space where she was her own person, "sexually and hence socially" (Frye 125). This challenge came in a society where "normal" women submitted to becoming sexual slaves or, more subtly, but just as degrading, "objects through which male homosocial bonds were secured" (Frye 128). The way in which a 
marriage forms a bond between two families does not go unnoticed by those with power. Fathers with power over a virgin daughter's body could exert control over their property by aligning it with whosoever they please, thereby forging profitable bonds from the trade of the flesh: human capital. Early modern drama however, as well as Romantic poetry, sweetens this rather bitter economy by heavily layering the reality with the rhetoric of a love narrative:

Rather than blatantly announcing that the role of the virgin in patriarchal society is simply that of a bargaining chip in a contractual agreement, early modern English society masks the virgin's role by situating it in a love narrative in which her primary gift to her beloved/betrothed is her bodily integrity. The bride's wellpreserved and extremely fetishized virginity allows her a valorized position within her society which is ceremonially reinforced by both her marriage and its consummation. (Jankowski 16)

This consummation represents the apex of a woman's triangulated worth and agency. After this fleeting moment, the no-longer-virgin is caught in a downwards spiral, crashing against the capstones of chaste wife and dutiful mother, all these being considered "natural" inclinations for a woman; giving gifts and rearing children, a series of selfsacrificial constructs created by men to ensure their continued dominance. Within the space of queer virginity, however, women can have the best of both worlds: they are both "objects of desire" and "desiring subjects" (Jankowski 18). It is important to distinguish here that these queer virgins do not, necessarily, want to be men, they simply do not want to be "women," as defined by men. 
As a nod to the virgin goddess Diana, these women wish to exist within a space where there is no property transfer, and thus no "fetishization of the hymen" (Jankowski 18) that binds them without the possibility of escape. The young maiden dreams of freedom from being the ideal of patriarchy, the good daughter that disavows her agency and permits male gods and mortals to use her body for sexual or economic interests. Homoeroticism can figure as one form of queer expression (certainly not exclusively), and it has a subtle yet indelible presence in narratives with cross-dressing such as that seen in As You Like It. As Jankowski puts it, "cross-dressing conventions...serve to foreground the instability of both gender and desire," (24) allowing to question a heteronormative notion of male-female desire as the only valid option. One such "crossdressing" example could be said to occur with Lamia's hybridization, with dual roles of serpent-woman and virgin-enchantress, which we will explore later in further detail. During one of the plays Jankowski examines, Neptune (standing as the epitome of male reason) implies that the love between two women is ultimately fruitless, and thus unjustified. This idea of an "unproductive sexuality” takes us back to Foucault’s claims of sex as a bio-political as well as commercial enterprise. Not surprisingly, the issue stands with the reproduction of capital; if the woman cannot produce heirs via this relationship, it becomes an "idle" and "foolish" pastime, relegated to the inconsequential whims of a child, instead of a love worth praising. In examining Keats's characterizations of female virgins, these women figure as "queer" not by any desire to be with another woman, but how their actions dismantle their contemporary construct of what it means to be a "woman." 
The connection between a queer understanding of the feminine and negative capability becomes clearer as we note their mutual efforts to resist absolute closure and definition. The pervasive uncertainty we see in the gender constructions and in the dream and ghost motifs of La Belle Dame, St. Agnes and Lamia reflect what Coleridge first described as "the willing suspension of disbelief" (Qtd. in Earl 23) and what Keats later reworked into "negative capability." Coleridge required this postponement of our "natural" inclination to be skeptical to allow for the acceptance of the supernatural in poetry. To fully appreciate poetry, truth becomes irrelevant; "faith" is necessary. The implication behind having faith then, is to suspend, as Keats described, that "irritable reaching after fact and reason," instead reveling in the "uncertainties, mysteries, and doubts” constitutive of life (Keats 41-42). This acceptance is essential to experiencing an “illusion” rather than a "delusion,” (Qtd. in Earl 24) particularly when reading Romantic poetry. As readers, we knowingly delve into the obscurity of the verse, which never intends to represent reality. By extension, the poet is also acknowledging his/her inability to represent reality. Re-presentation is unfounded, as Keats describes in another letter to Richard Woodhouse:

As to the poetical Character itself...it is not itself—it has no self—it is everything and nothing — it has no character—it enjoys light and shade; it lives in gusto [power or passion defining any object]...what shocks the virtuous philosopher delights the chameleon Poet...a poet is the most unpoetical of anything in existence, because he has no identity...not one word I ever utter can be taken for granted as an opinion growing out of my identical nature—how can it, when I have no nature? (Keats 147-148). 
Giddy with candor, Keats disavows any truth his words may claim—-though he takes care to say them anyway. In this crisis of identity, Keats reveals the fundamentally ephemeral nature of both the poet and poetry, and by extension, the conditionality of gender constructs as well. We experience the clash of philosophy and poetry he mentions most poignantly in Lamia, when Lamia's mystery is callously stripped by the logocentric Appollonius. David Wood re-imagines Keats's negative capability as the "step back." He says the step back does not "claim that truth has been left behind, and that we must return to it," but rather that "truth" is in constant circulation and resists any closing off:

The step back is in this sense a movement away from the rush of dialectical enthusiasm for moving forward and overcoming...it insists on the danger of closing off such a connection, or attempting to subject it to law or a rule. The step back marks a certain shape of philosophical practice, one that does not just resign itself to, but affirms the necessity of, ambiguity, incompleteness, repetition, negotiation, and contingency. (3-4)

While Keats described the ambiguity of a poet's identity, Wood extends this uncertainty to encompass our being-in-the-world. Rescinding from strict categorization, the feminine body can also be said to represent the origin and the Other, as The Belle Dame can be both the lover and the destroyer of the knight. Her role begins in tandem with Madeline, the male gaze is turned upon the virgin with intention to ravish and (possibly) convert her into a wife, although perhaps not in that order. La Belle Dame begins with the knight admiring her beauty and physically taking her, ending with the usurpation of his identity—an emasculation of sorts. In other words, The Belle Dame has progressed from being the object of the male gaze, to returning that gaze in lethal proportions. The 
knight’s identity has “withered” just as Keats contended the poet’s identity does when creating his/her art. A number of dichotomies are revealed to us in this ballad: "Eros and death; temptation and duty; dream and waking; and the murky suffering of the consequences of ungoverned emotion; ecstasy and its aftermath of despair; the otherworldly seductress... or the poetic muse herself" (Earl). This series of dualities only highlights the shadowy space between and the role of the reader to embrace its nuanced and/or indeterminate meaning.

With La Belle Dame, Keats "[redefines] the typical chivalric masculine tropes by positioning the knight as the one who needs rescuing" (Mayrhofer 40). The knight's disempowerment continues by accepting food from the "faery's child" (Keats 14) who feigns innocence but has the knight in her thrall, both sexually and magically. Though the food is described as "roots of relish sweet, And honey wild, and manna dew," (La Belle Dame 25-26) they are in juxtaposition to the intoxicating belle dame; sweet as "honey" and sensually "wild," but not complementary to the knight's masculine identity nor (perhaps as a direct result) his physical health. Confronting difference in the feminine Other is a threatening experience for the patriarchal subject, and it hinges on the feminine sexual mystery and prowess. La Belle Dame is initially presented in an ambiguous state, but one can fairly surmise she is at least a performative virgin, given her apparent innocence and the knight's ravenous attraction for her. This assumption allows the knight to perform the role he is so accustomed to, basking in his power over her as their intimacies transpire. At the ballad's conclusion however, it becomes clear that the knight was not the dame's sole lover, nor her only victim for that matter. Her power lay in her ability to masquerade as the alluring virgin; beautiful, dewy-eyed, guileless: the 
proverbial empty cup waiting to be filled by a man. The image of The Belle Dame resembles that of a pagan goddess, enticing but unattainable, exploiting the mortal male ego to chase her in spite of her lethality: "Her hair was long, her foot was light,/ And her eyes were wild" (15-16). This mask of the untamed, untouched virgin allowed her to ensnare all the "pale kings and princes...warriors" (37-38); none were immune to her deadly charm. The Belle Dame takes both masculinity and life, the implication being that without phallo-centric agency (as having, rather than surrendering control), life becomes a shadow of its former self. The duality of her nature is reflected in the dream-state pervading the ballad, as the knight describes his fall from both reality and subjectivity: "And there she lulled me asleep,/ And there I dream'd--Ah! Woe betide!/ The latest dream I ever dream'd/ On the cold hill's side" (33-37). This marks the end of the knight's natural life; he has joined the inauspicious ranks of those that have succumbed to female power, serving as a painful patriarchal reminder of what happens when women are given the upper hand.

Before our discussion on Keats's St. Agnes, it is useful to examine Saint Agnes as a historical figure and the symbolic significance of a woman who refused to sacrifice her virginity. Though accounts vary as to the details surrounding her death, she was generally thought to have been between the ages of twelve and thirteen, and a Christian in the middle of a largely pagan Rome. In spite of intense pressure, even torture, she refused to give up her virginity through marriage, arguing that she would only give her virtue to Christ. Although having many offers of marriage, she vehemently refused, and was executed, either by burning, beheading, or stabbing. She later became known as the patron saint of virginity. Young maids would practice a series of rituals on The Eve of St. 
Agnes in the hopes of securing a husband for themselves ("Agnes"). So it was that Agnes's martyrdom ironically spurred the opposite ideal in ensuing culture: chastity in marriage rather than virginity for the virgin's sake.

The Eve of St. Agnes begins with a pious man who suffers from the cold and yet prays for those that are enjoying warm revelries. Though the revelers are "numerous" (39) and boisterous, they lose significance, being described as "shadows haunting fairily," giving a supernatural quality to the scene before us. The dream sequences also add an element of unreality, as with the "old dame[s]" (45) myth about St. Agnes’ Eve, and with later references we will explore.

Madeline's "maiden eyes" are described as "divine" (57) perhaps by virtue of them belonging to a virgin, a virgin that bursts with the "whim" (line 55) of finding a proper husband that is worthy of taking her honor, (read: virginity). Returning to an earlier stanza, there are connections drawn between the role of the virgin and the aesthetic "cleanliness" as in the "lily white beauties" mentioned in line 52, implying that purity is contingent on the intactness of the hymen, not to mention its "whiteness." Attached to this image of purity is the negative connotation associated in her being “hoodwink'd with faery fancy,” suggesting a flaw specific to her gender and also corroborating a later claim that she is a victim of circumstance and intentional manipulation. Madeline's credulity is ultimately her undoing, and though the last stanzas of the poem are dreamily ambiguous, it seems she is dis-honored without any clear marital future that ensures her social status.

In reality, Angela leads Porphyro into Madeline’s bed-chamber not because she is convinced by his assurances of propriety, but because he threatens to rouse the entire 
company, placing himself in peril as well as Angela, for allowing a mortal enemy to enter. She understands full well what Porphyro intends to do to Madeline — evident in her chiding him in the latter half of stanza 16, calling him "cruel," "impious,” (140) and “wicked” (143) for his ignoble machinations. Over and over, Madeline becomes a material good that can be negotiated upon, for personal gain from both parties.

In stanza 19 we once again encounter the supernatural dream-state which acts as a foil for the righteous, yet manipulated, character of Madeline. Porphyro is admitted by Angela into "Madeline's chamber" (164) which starts to function as a metaphor for her virginity; kept hidden and well protected until some negotiation has been made. Invoking Jankowski's aforementioned virginal qualifiers, "chaste, silent, obedient," Madeline's "chamber" is described as "silken, hush'd, and chaste" (187), where Porphyro "took covert, pleased amain" (188). Instead of approaching Madeline as an equal, Porphyro hides, all the better to "see her beauty unespied" (166). Taking advantage of this night's significance, "While legion'd faeries pac'd the coverlet,/ And pale enchantment held her sleepy-eyed," (168-169) Porphyro awaits the perfect opportunity. Sleep, dreaming, and "magic" keep Madeline in a blind, delusional state, quite different from the willing "illusion” that Coleridge described. Apparently, reality is a space inhabited by the dishonorable, who then prey upon those foolish enough to dream--that is, the virgin. In stanza 22, Madeline is still entranced in a vulnerable state-“like a mission’d spirit, unaware” (193). Madeline’s inability to speak only highlights her powerless condition further. Line 243, “As though a rose should shut and be a bud again” reveals the untenability of this regression, emphasizing the irrecoverable value of her virginity. Indeed, stanza 37 shows that instead of the reputed post-coital glow, Madeline expresses a deep- 
seated fear of being abandoned as if she were a bird made helpless by a clipped wing. The symbol of her maidenhood has been taken and she fears being left like a "dove forlorn” (333). Later in stanza 39, Porphyro seems to honor his promise to make her a wife and share his home. They elope, but now they find themselves in a world of frightful supernatural phenomena together: “elfin-storm from fairy land,” (343) “sleeping dragons,” (353) “phantoms,” (361, 362) “witch,” “demon” (374).

Critic Susan Wolfson sees Madeline as a figure of "undecided" characterization, viewing her as "as an innocent dreamer, an object of rapt devotion, a subject of soft ridicule, and a target for appropriative designs, opportunistic manipulation, and, some have argued, calculated betrayal" (Wolfson 83). Madeline as the "innocent dreamer" first appears when she was told of St. Agnes's Eve, when young virgins must go to bed without supper and without looking anywhere but upwards towards heaven, asking for a future husband. When Prophyro beholds her, he is in rapture, but of an object that he must possess, revealing the agency belongs to him, not Madeline. He becomes the rupturing and thereby, defining agent in the narrative of Madeline's life as she transitions, rather emotionally, from virgin to non-virgin. In such agency we see the "appropriative designs" and "manipulation" that Wolfson proposed, with Porphyro as the triumphant owner and Madeline as the unfortunate product.

Despite these general victimizations, however, Mary Arseneau holds that Madeline also exacted a kind of power (albeit unwittingly) over Porphyro, using her body as a source of entrancement. Her feminine virginity held reality at bay, muffling it with the drowsiness of sleeping and dreams, but mostly desire. Arseneau describes her as "alternately saintly and enchanting, inspiring and tempting, passive and powerful, the 
depiction of Madeline is both an expression of Keats's often-noted ambivalence towards the female figure and a model of his increasingly self-conscious treatment of the male construction of the feminine" (Arseneau). Her power lies in her ability to divert the male psyche into an indistinguishable state between dreaming and waking. During what Porphyro enjoys as sensual undressing in stanza 26, Madeline is described as "halfhidden, like a mermaid in the sea-weed" (231), suggesting the sirens of Greek myth. These woman-creatures would lure men with a radiant beauty, only to destroy them once captured. Porphyro describes himself as spellbound when he first speaks to her, saying, "And now, my love, my seraph fair, awake!/Thou art my heaven, and I thine eremite:/ Open thine eyes, for meek St. Agnes' sake,/ Or I shall drowse beside thee, so my soul doth ache." (276-279) Once again invoking the notion of purity, he describes her as an angel of the highest rank in Christian celestial hierarchy, with him becoming a devout recluse of her heavenly body. After trying and failing to rouse her from her sleep, he "mus'd awhile, entoil'd in woofed phantasies" himself, falling momentarily into a similar rapture (288). Most telling of Madeline's hidden power perhaps, apart from their eventual elopement turning them into ghostly wreaths, is Porphyro's decision to play "La belle dame sans mercy" (292) for her. It seems to be an acknowledgement on his part of her overwhelming influence on him, and, given the ending, an omen for feminine-induced mortality.

Keats's capacity to polarize female characters, rendering them either "fair maids [or] femmes fatales" (Waldoff 54) is countered by the equally surprising union of these two characterizations. Seamlessly, Keats is able to depict an individual such as La Belle Dame, Madeline, or Lamia "as if she possesses two opposing natures, one engaging and 
seductive, the other abandoning and pitiless" (Waldoff 55). They exist in the space between — as neither one nor the other. After composing St. Agnes, Keats seemed to tease the possibilities between purely virtuous and evil in the characters of La Belle Dame and Lamia. These women are hybrids of a sort, straddling the binaries of natural/supernatural and innocent/calculating. The threat of the feminine is present in Madeline's undressing in lines 226-35. Though innocently removing her garments, her actions become a sensual striptease under the potent male gaze. The result is an objectification of her innocuous actions as a sexual baiting to draw the male out of the phallo-centric realm into that of the feminine uncanny. Though Madeline is the most subtle of the three, Lamia, and especially La Belle Dame, constitute a feminine "queerness" that is as threatening as it is indeterminate.

As with their characterizations, the plots of these poems suggest an uncanniness not easily rationalized. The dream-like sequences in St. Agnes open a range of possibilities and interpretations, such as Porphyro and Madeline's elopement. They flee the castle and the narrative, leaving behind a disembodied trace of their being, not fully present nor absent in the material world: "They glide, like phantoms, into the wide hall; / Like phantoms, to the iron porch, they glide" (361-62). Inside the castle there is also a phantasmal effect as two of its inhabitants leave: "the bolts full easy slide/ The chains lie silent on the footworn stones/ The key turns, and the door upon its hinges groans" (3679). It is as though they are- to borrow from Hamlet—shuffling off their mortal coil to merge with the haunted castle. Like ghosts, they are stripped from whatever predetermined "essence” they had, and escape. 
To better engage with Lamia and the symbolic ramifications of Keats's choice for an Echidna, or snake-woman, we will briefly explore the semantic, historical, and literary origins of the term "serpent." The term is etymologically linked to a 'crawling' creature. It comes from the Latin word serpēns, while a verb use of the Old French serpere would mean to ‘crawl, creep'. It was also a close relative of the Greek hérpein, or 'creep’, from which English gets herpes [17] (etymologically the 'creeping' disease) (“serpent”).

Extending across the symbolic dichotomy, serpents can represent both a lethal presence and a clandestine absence. They "sidle, or meander" noiselessly on their bellies, but then rear upon their prey and "strike without warning from grass or coverts." Indeed, many cultures believe serpents are said to "fascinate" their prey; transfixing them into a dazed state and then attacking. Snakes, or serpents, can represent a mortal danger, being both venomous and "subtle" or sneaky. While their appearance may be outwardly beautiful—for example, their iridescent skin—it is not a sign of inward or permanent beauty, since they regularly shed this marker. This masking trait, though clearly connected to Lamia's transformative abilities, would also be an apt description of La Belle Dame, as she ensnares men with an alluring, seemingly feeble shell and kills them with a supernatural inner strength.

The biblical reference to snakes would be the most pervasive in Western literature. Here the serpent tempts Eve into eating from the tree of knowledge of good and evil. When she succumbs, this brings about the expulsion of Adam and Eve from the Garden of Eden and the advent of suffering and death. The serpent, as an allegory for Satan, was "more subtil [sic] than any beast of the field" and susceptible Eve was powerless against him (Gen. 3.1-7). St. Paul worries that "as the serpent beguiled Eve 
through his subtlety," the minds of Christians might be "corrupted from the simplicity that is in Christ" (2 Cor. 11.3). The serpent was thus connected with "knowledge or wisdom, though a false or even fatal knowledge, and with human mortality" ("Serpent"). Similarly, the women in Keats's poetry, even the harmless Madeline, seem to exploit the male desire to "know" a woman, intimately and otherwise. Tellingly, to "know" a woman (to remove the mystery that stands as an obstacle) is to seal your doom, as we see with the knight, Lycius, and arguably Porphyro as well.

In the Cambridge Dictionary of Literary Symbols, the serpent is traced from the Greek tradition, to biblical lore, to early modern England. Homer and the Greeks in general see a "great sign," or omen in the snake (drakon). In the Iliad for example, if the snake consumes eight bird nestlings along with their mother, the observer interprets this to mean that nine years must pass before they attack the city of Troy. It is as though the snake symbolizes time, or eternity, which swallows the birds (years). The Christian scheme describes the serpent of Eden becoming "the great dragon," or "that old serpent, called the Devil, and Satan, which deceiveth the whole world” (Rev. 12.9); "Oure firste foo, the serpent Sathanas,” in Chaucer’s phrase (Prioress’s Tale 1748); “The infernal Serpent” of Milton (PL 1.34). Goethe’s devil Mephistopheles invokes “my aunt, the famous snake” (Faust I 335). The “dreadful Dragon” that Spenser’s Redcrosse Knight vanquishes after a terrible battle (FQ 1.11.4-55) is the dragon of Revelation, and the Knight reenacts the victory of Michael and the angels (Rev. 12.7). ("Serpent" Cambridge) Behind these connections lies the notion that serpents are themselves immortal because they shed their skins and thus replenish their physical beings. Their wisdom then might be due to sheer great age, while appearing otherwise. So despite the serpent's evil 
connotations, or perhaps intimately connected to it, the snake's deceitful nature is seen as a manifestation of its egregious wisdom. Interestingly, Christ invoked his followers to be “wise as serpents” (Matt. 10.16). ("Serpent" Brewer's)

The serpent may be symbolic of eternal renovation and the art of healing, but only for itself. Having the power to shed its skin not only shows its duplicitous talents, but also poses the uncanniness of growing young again at will, retaining the truth (age) safely inside where no one can see. In this ability to hide its true form, it can represent an incarnation of Samael, or the Devil. As the Tempter (Genesis 3:1-6), in some early depictions the serpent (the Devil) is located under the feet of the Virgin Mary, alluding to Eve after the Fall (Genesis 3:15), a constant reminder that women, no matter how chaste, are especially susceptible to the temptation lurking at their feet ("Serpent" Brewer's).

Keats takes on an entirely novel approach to the serpent, morphing the creature with the body and mind of a woman, rendering its nature ethically dubious instead of wholly evil. The title character inhabits a grey area of moral integrity and gender positioning suggestive of the shadowy depths in negative capability. It is useful to start our discussion on Lamia with Keats' own allusion from Burton's Anatomy of Melancholy:

...a young man twenty-five years of age...met such a phantasm in the habit of a fair gentlewoman, which taking him by the hand...told him she was a Phoenician by birth, and if he would tarry with her, he should hear her sing and play, and drink such wine as never any drank, and no man should molest him; but she, being fair and lovely, would live and die with him, that was fair and lovely to behold. The young man, a philosopher, otherwise staid and discreet, able to 
moderate his passions, though not this of love, tarried with her awhile to his great content, and at last married her, to whose wedding, amongst other guests, came Apollonius; who, by some probable conjectures, found her out to be a serpent, a lamia; and that all her furniture was, like Tantalus' gold, described by Homer, no substance but mere illusions. When she saw herself descried, she wept, and desired Apollonius to be silent, but he would not be moved, and therefore she, plate, house, and all that was in it, vanished in an instant... (Qtd. in Keats 359) The narrative of Keats' poem begins, just as detailed above, with Lamia being trapped in a serpent's body. Throughout the story, many narrative gaps are left—perhaps intentionally—open to allow for a more sympathetic reading of Lamia's character. Her main redeeming feature is her love for Lycius that somehow voids her "evil" appearance: "Her throat was serpent, but the words she spake/ Came, as through with bubbling honey, for Love's sake" (I.64-65). From the beginning then, she is presented as the figure enshrouded in the female uncanny. In describing her paradoxically as both a "penanced lady elf" and "demon's mistress, or the demon's self," Lamia can represent the two sides to evil, Samael (Satan) and Lilith (Satan's mistress) (I.55-56). Yet the "penanced" quality suggests that she is a victim of her situation, not in full control as the devil or its mistress would be. So in these two contradictory lines the speaker rightly views Lamia as a figure of paradox, fully feminine in her mystery. This mystery (or the unraveling of it) ultimately leads to the doomed romance between Lamia and Lycius, but the subplot that serves as an introduction also reveals much about Lamia, her person, and her power. She has kept the nymph hidden from the male gaze and ensuing domination, reminiscent of a Diana-like goddess. Diana was of course, a virgin, but a queer one. Not only did she 
challenge the role of her sex by hunting, she also held power over other virgin's bodies. Having them follow her as her disciples, she opposed heterosexual relations that would render them objects. By exerting this control over their anatomies, she ironically performed the male role, while subverting patriarchy. The power was not handed over to a husband, but retained by her. In the same way, Lamia expertly negotiates the nymph's body, exploiting Hermes's desire. She says, "by my power is her beauty veil'd/ To keep it unaffronted, unassail'd/ By the love -glances of unlovely eyes...Her loveliness invisible, yet free/ To wander as she loves, in liberty" (I.100-103, 108-109). Lamia only trades in the commodity of the nymph's body after she is assured that Hermes will "grant [her] boon" (I.111): to become a woman once more. This sexual economy is made unorthodox by Lamia's position as chief negotiator, while Hermes must comply with the terms. The initial image of him as a predator over Lamia—-Hermes on his pinions lay/ Like a stoop'd falcon ere he take his prey" (I.66-67) is dispelled by her shrewd contract. This parallels the image of the snake caught in the eagle's talons, yet rearing up and sinking its venom into its would-be assailant. Though she demonstrates this initial challenge worthy of a queer virgin, Lamia is ultimately pulled into the patriarchal undercurrent of the narrative.

There are several references to dreaming, or the indistinguishable state of reality versus unreality. The first and most obvious instance comes during Lamia's transformation, when the speaker reflects, "It was no dream; or say a dream it was,/ Real are the dreams of Gods, and smoothly pass/ Their pleasures in a long immortal dream" (126-128). The absence of information regarding Lamia's origins, the supernatural quality with which she affects her surroundings, and her inexplicable apparitions and 
disappearances, all add to the feeling that we are in a moment where reality is suspended. After her torturous transformation, she is "bereft" (I.163) of all her Gordian beauty, and "nothing but pain and ugliness were left" (I.164). In one of many unexplained disappearances, she melts away and even the power of speech deserts her. This moment appears as an undressing of agency similar to that of Madeline's in St. Agnes. Now in female human form, Lamia becomes susceptible to the antics of a male-controlled society, whereas before she was figuratively and literally impregnable. She is even capable of projecting her dreams as a sort of spell, lending a surreal quality to her dealings with Lycius. When he first met her, "as...from one trance [he] was wakening/ Into another..." (I.296-297), and when he observes her dismay at encountering Appollonius, he reflects that "...to-night [Appollonius] seems/ The ghost of folly haunting [his] sweet dreams" (I.377) with bitter reality.

The sexual economy is reinforced by the image of the alluring, "pure" virgin: "for she was a maid/ More beautiful than ever twisted braid" (I.185-186). With this caricature of the blushing maiden, there is the suggestion of this being the only way to truly lure in Lycius; indeed, the only way to a man's heart seems to be through the express relinquishment of feminine power. She understands "That Lycius could not love in half a fright/ So threw the goddess off, and won his heart/ More pleasantly by playing woman's part" (II.335-337). Here we see that Lamia must veil her power, donning the disguise and employing the performance of the submissive maid so as to not pose a threat to Lycius.

Furthering the mystery constitutive of woman, Lamia is presented as a queer virgin in her sexual prowess that seemingly comes a priori: "A virgin purest lipp'd, yet in the lore/ Of love deep learned to the red heart's core" (I.189-190). She is also 
unconventional in her reversal of roles. Lamia actively pursues Lycius rather than the other way around. Yet when he is charmed by her beauty and apparent "purity," she exploits this opportunity to play coy, asking what she will get in return for her extraordinary sacrifice in eloping with him. In her last show of "queerness," she fervently resists marriage, "...[weeping] a rain/ Of sorrows at his words; at last with pain/ Beseeching him, the while his hands she wrung,/ To change his purpose" (II.66-69). Lamia's tragic downfall is connected with her eventual renunciation of her queernessher resistance — and thereby her agency as a woman.

Lamia's indecipherability and unconventional behavior is a testament to the futility of understanding women as fixed gender constructs. Woman is the figure of paradox, since her body can represent both origin (as mother) and other (in opposition to the phallus) (Hurst 267). Representing both sides to the structuralist binary coin of origin/difference, the virgin is a particular threat to men, since she can decide to remain as such. Lamia adds another dimension to this difference, being trans-species in addition to trans-gender (trans-gender here refers not to biological but behavioral ambiguity). The challenge lies in materially claiming the virgin, as does Lycius with Lamia. Not satisfied simply with having her avowal of love, he thinks of her as a "prize" (II.57), and he wants other men to be "confounded" and "abash'd" (II.58) upon beholding what is his. In short, he wants to marry. In this moment, it is not difficult to see marriage as a patriarchal institution; a confirmation of the male need to dominate and claim the virgin as a commodity. Indeed, Lycius is "...stung,/ Perverse, with stronger fancy to reclaim/ Her wild and timid nature to his aim" (II.69-71) when she resists his proposal, taking "...delight/ Luxurious in her sorrows, soft and new" (II.73-74). Lamia, blinded by 
uninterested affection, acquiesces to Lycius's will and makes another tragic transformation: from queer virgin to submissive maid of patriarchy. The speaker scoffs at any leftover insinuation that she had a serpent's nature, for "She burnt, she lov'd the tyranny,/ And, all subdued, consented to the hour/ When to the bridal he should lead his paramour...And knowing surely she could never win/ His foolish heart from its mad pompousness,/ She set herself, high-thoughted, how to dress/ The misery in fit magnificence" (II.81-83, 113-116). No longer able to straddle the dichotomy between resistant/submissive, Lamia knows she can no longer evade commodification through marriage, so she sacrifices her subjectivity in becoming materially objectified. The expert negotiator finds herself on the losing end of this bargain, for the sake of her love.

The structural philosophy inclined towards Western metaphysics and relying on logos and fixed binaries as its foundation discredits any obscure and fluid subjectivity. In doing so however, much is lost:

Philosophy will clip an Angel's wings,

Conquer all mysteries by rule and line,

Empty the haunted air, and gnomed mine-

Unweave a rainbow, as it erewhile made

The tender-person'd Lamia melt into a shade. (II.234-238)

As we discover in the last lines of Lamia, it was this willing suspension of belief that led to both Lamia and Lycius's undoing. In a phallogocentric society however, the mystery of woman must be known to man, preferably sooner rather than later. It creates a palpable anxiety when virgins (their short-lived independence as well as their hymens) remain enclosed against the penetration of the man (their control and their penis). To this end, 
Appollonius's destructive gaze is turned upon her and unmasks her, but for Lamia, to be masked is to be alive.

At the tragic revelation, Appollonius's gaze functions like a serpent's fang: a "sharp spear [that] went through her utterly,/ Keen, cruel, perceant, stinging" (II.300-301) with the venom of truth, effectively closing off any further possibilities. Appollonius is the figure of male logocentrism; the philosopher who is incapable and unwilling to "suspend his disbelief," thereby becoming the true serpent, the true villain—wise only for evil ends. Earlier in the story, Lycius had asked for her "appellation" (II.89) or a name, but she doesn't even have that as a signifier of a fixed identity. Appollonius undoes her with the combination of the gaze and the uttering of a name; "Serpent!" (II.305)—a name that fixed her identity and thus destroyed her subjectivity in the human world. Appollonius ultimately unmasks Lamia, trying to reveal a truth or telos that was never there, or fades as soon as one tries to ascertain it.

Running the gamut of feminine identities from fully compliant to deadly transgressive, all three virgins that appear in this selection of Keats's poetry nonetheless represent difference and otherness when facing patriarchy. Though Madeline exemplifies the good daughter of patriarchy, seamlessly filling the prescribed role, she still emerges for Porphyro as a figure of enchantment. In spite of this transient power, Madeline's agency was as short-lived as her virginity. She is left bereft from the power of the unknown when Porphyro asserts himself as her defining agent, rendering her a non-virgin and therefore subject to his will in marriage. Yet for that fleeting stretch of time as a maiden, she held power over the masculine subject with her on-demand "virtue." In stark contrast, La Belle Dame wields a destructive power over the masculine subject, dangling 
her "purity" as bait. However, she can also be read as the innocent bystander, to whom men are drawn in their efforts to conquer. These efforts end in emasculation, although not necessarily of her intention — perhaps she simply represents the threat of the feminine "Other" in lethal proportions. She is a queer virgin that exploits the physical qualities that patriarchy so covets—-with toxic ends. On a mercilessly serial basis, she reduces the masculine identity to a shadow of its former self. Finally, Lamia demonstrates an even more nuanced understanding of "queerness," in a transcendental challenge to the species as well as the virgin's role. Her brief power came from donning the mask of ambiguity, a parallel expression of the same negative capability Keats himself espoused. As he neared his last stretch of life, all became insubstantial for Keats, with his beloved Fanny's figure "eternally vanishing" and him questioning whether he "shall...awake and find all this a dream..." (Keats 376-377). In like fashion, all three pieces discussed herein end with uncanny disappearances, reminding us that any effort to pin down absolute meaning would indeed be like the poet's life and work: captivating, but as ephemeral as a ghost or a dream. 


\section{CONCLUSION}

The selections from Shakespeare's tragedies and comedies showed us how the masquerade can be an expression of gender fluidity, and in turn a reactionary move against the phallocentric hierarchy. It also provided a textual basis for the phenomenon of the new husband's transition into second father.

With Spenser, we explored the institution of heterosexual marriage in early modern England as a marker of the virgin's commodification. The virgin becomes the valuable object (insofar as her hymen is intact) around which the entire patriarchal tradition is based. Just as with Shakespeare's works, we see how father and husband enter the flesh economy, becoming merchant and consumer. In spite of this, queer virgins like Britomart revolt against this via their rejection of marriage as well as prescribed roles.

Finally, Keats's poetry provided us with the opportunity to revisit how the queer virgin disassembles the concept of heteronormativity. The masquerade became a function of the queer virgin in her challenge to marriage, fixed gender dichotomies and roles, and male-dominated society itself. This intentional muddling ultimately came to reify Keats's notion of "negative capability." This is what the queer virgin does-confuses what should never be clear for the sake of one at the expense of another. 


\section{BIBLIOGRAPHY}

"Agnes." Brewer's Dictionary of Phrase and Fable. London: Chambers Harrap, 2009. Credo Reference. Web. 28 March 2013.

Arseneau, Mary. "Madeline, mermaids, and medusas in 'The Eve of St. Agnes.'." Papers on Language \& Literature 33.3 (1997): 227. Academic OneFile. Web. 18 Mar. 2013.

Butler, Judith. Gender Trouble: Feminism and the Subversion of Identity. Taylor \& Francis Routledge, 1999. Print.

Callaghan, Dympna. Introduction. A Feminist Companion to Shakespeare. Malden, MA: Blackwell, 2000. Print.

Doane, Mary Anne. "Film and Masquerade; Theorising the Female Spectator." Screen 23 (Sep.- Oct. 1982): 74-87.

Doty, Alexander. Making Things Perfectly Queer. Minneapolis: University of Minnesota Press, 1993.

Earl, Martin. "La Belle Dame Sans Merci: Beyond Self Expression" By John Keats : Poem Guide : Learning Lab : The Poetry Foundation. Poetry Foundation, n.d. Web. 4 Mar. 2013.

Finucci, Valeria and Schwartz, Regina. (ed.) Desire in the Renaissance: psychoanalysis and literature. Princeton University Press, 1994. Print.

Frye, Marilyn. "Willful Virgin or Do You Have to Be a Lesbian to Be a Feminist?" Willful Virgin: Essays on Feminism 1976-1992. Freedom, California: Crossing Press, 1992. 124-37.

Foucault, Michel. The History of Sexuality. Vol. 1. New York: Pantheon, 1978. Print.

Gay, Penny. As she likes it: Shakespeare's unruly women. Psychology Press, 1994. Print. 
Hennessy, Rosemary. Materialist Feminism and the Politics of Difference. New York: Routledge, 1993.

Hoberman, Ruth. "Masquing the phallus: genital ambiguity in Mary Renault's historical novels." Twentieth Century Literature 42 (1996): 277-93. Print.

Hurst, Andrea. Derrida Vis-à-Vis Lacan: Interweaving Deconstruction and Psychoanalysis. New York: Fordham UP, 2008. Print.

Jankowski, Theodora A. Pure Resistance: Queer Virginity in Early Modern Drama. Philadelphia: University of Pennsylvania, 2000. Print.

Keats, John. Complete Poems. Ed. Jack Stillinger. Cambridge, MA: Belknap of Harvard UP, 1982. Print.

Keats, John. Selected Letters. Ed. Robert Gittings and Jon Mee. Oxford: Oxford University Press, 2002. Print.

Lacan, Jacques, Juliet Mitchell, and Jacqueline Rose. Feminine Sexuality: Jacques Lacan and the École Freudienne. New York: W.W. Norton, 1985. Print.

Mayrhofer, Amy Lauren. "The Woman in the Magic Web: Empowered Or Entrapped? Female Agency in Keats and Coleridge Vs. Female Stereotypes in Tennyson and Christina Rossetti." Southern Connecticut State University, 2012. United States -Connecticut: ProQuest. Web. 2 Apr. 2013.

Newman, Karen. "Portia's Ring: Unruly Women and Structures of Exchange in The Merchant of Venice." The Merchant of Venice: Norton Critical Edition: W. W. Norton \& Company, 2005. Print.

Sedgwick, Eve Kosofsky. "Queer and Now." Tendencies. Durham: Duke University Press, 1993.

"Serpent." A Dictionary of Literary Symbols. Cambridge: Cambridge University Press, 2007. Credo Reference. Web. 25 February 2013. 
"Serpent." Brewer's Dictionary of Phrase and Fable. London: Chambers Harrap, 2009. Credo Reference. Web. 25 February 2013.

"serpent." Word Origins. London: A\&C Black, 2006. Credo Reference. Web. 25 February 2013.

Shakespeare, William, and Frances Dolan (Ed.). As You Like It. Penguin Classics, 2000. Print.

Shakespeare, William, Andrew Hadfield (Ed.). King Lear (Barnes \& Noble Shakespeare). Barnes \& Noble Shakespeare, 2007. Print.

Shakespeare, William, Nicholas Radel (Ed.). Othello (Barnes \& Noble Shakespeare). Barnes \& Noble Shakespeare, 2007. Print.

Shakespeare, William, and Julie Crawford (Ed.). The Merchant of Venice. New York: Barnes and Noble, 2008. Print.

Shakespeare, William, Nicholas Radel (Ed.). The Taming of the Shrew (Barnes \& Noble Shakespeare). Barnes \& Noble Shakespeare, 2007. Print.

Shakespeare, William, Nicholas Radel (Ed.). The Tempest (Barnes \& Noble Shakespeare). Barnes \& Noble Shakespeare, 2007. Print.

Waldoff, Leon. Keats and the Silent Work of Imagination. Urbana: University of Illinois Press, 1985.

Wolfson, Susan J. "Keats's `Gordian Complication' of Women." Approaches to Teaching Keats's Poetry. Eds. Walter H. Evert and Jack W. Rhodes. New York: MLA, 1991. 77-85.

Wood, David. "Toward a Negative Capability." Introduction. The Step Back: Ethics and Politics after Deconstruction. Albany: State University of New York, 2005. 1-8. Print. 